\title{
Simulating ectomycorrhizal fungi and their role in carbon and nitrogen cycling in forest ecosystems
}

\author{
G. Deckmyn, A. Meyer, M.M. Smits, A. Ekblad, T. Grebenc, A. Komarov, and H. Kraigher
}

\begin{abstract}
Although ectomycorrhizal fungi play an important role in forest ecosystem functioning, they are usually not included in forest growth or ecosystem models. Simulation is hampered by two main issues: a lack of understanding of the ecological functioning of the ectomycorrhizal fungi and a lack of adequate basic data for parameterization and validation. Concerning these issues, much progress has been made during the past few years, but this information has not found its way into the forest and soil models. In this paper, state-of-the-art insight into ectomycorrhizal functioning and basic values are described in a manner transparent to nonspecialists and modelers, together with the existing models and model strategies. As such, this paper can be the starting point and the motivator to include ectomycorrhizal fungi into existing soil and forest ecosystem models.
\end{abstract}

Key words: ectomycorrhizae, forest ecosystem, soil, model, review, simulation.

Résumé : Même si les champignons ectomycorhiziens jouent un rôle important dans le fonctionnement des écosystèmes forestiers, ils ne sont habituellement pas inclus dans les modèles d'écosystème ou de croissance forestière. Deux problèmes principaux compliquent l'utilisation des modèles de simulation : un manque de compréhension du fonctionnement écologique des champignons ectomycorhiziens et l'absence de données de base adéquates pour le paramétrage et la validation. Beaucoup de progrès a été accompli au cours des quelques années passées au sujet de ces questions mais cette information n'a pas été intégrée dans les modèles édaphiques et forestiers. Dans cet article, les connaissances les plus récentes concernant les données de base et le fonctionnement des ectomycorhizes sont présentées de façon transparente pour les profanes et les modélisateurs. En soi, cet article pourrait servir de point de départ et de motivation pour inclure les champignons ectomycorhiziens dans les modèles édaphiques et d'écosystème forestier existants. [Traduit par la Rédaction]

Mots-clés : ectomycorhizes, écosystème forestier, sol, modèle, examen, simulation.

\section{Introduction}

Most (80\%-90\%) trees in temperate and boreal forest ecosystems live in symbiosis with ectomycorrhizal (EM) fungi (Read 1992). These fungi receive energy from their host plant and, in return, deliver key tree nutrients such as nitrogen $(\mathrm{N})$ and phosphorus $(\mathrm{P})$. As most root tips of EM host trees are covered by EM fungal tissue, these fungi form the main interface between the tree and the soil (Read et al. 2004). Therefore, EM fungal functioning has to be acknowledged in studying soil-plant interactions (for a review, see Smith and Read 2008). There is growing attention concerning the role of EM fungi in ecosystem and soil-forming processes, as illustrated in several reviews in the field of soil organic matter (SOM) dynamics (Read and Perez-Moreno 2003; Talbot et al. 2008) and soil mineral weathering (Landeweert et al. 2001; Finlay et al. 2009), but up to now, EM fungi have been widely ignored in forest soil models.

Concerning the role of arbuscular mycorrhizal (AM) fungi, intracellular fungi mainly found in grasslands and tropical rainforest, besides research articles, some excellent modeling studies have been performed (Collins Johnson et al. 2006; Schnepf and Roose 2006; Deressa and Schenk 2008). For EM fungi, extracellular symbiotic fungi found mostly in temperate and boreal forests, emphasis has been on experimental studies, but inclusion into forest and soil models has so far been rather limited. Nonetheless, some models for EM fungi growth exist (Meyer et al. 2010; Deckmyn et al. 2011; Orwin et al. 2011). In this manuscript, a review of the main data and processes that are potentially important for simulation of EM fungi in forests is given. Furthermore, a review of the existing models is supplied. Because of the very limited number of EM models, some relevant AM models are also included. The purpose of this review is to stimulate the development and improvement of existing soil models through inclusion of the most important EM mechanisms and effects. Furthermore, by listing the main data requirements for development and validation of forest soil models, we hope to stimulate experimental scientists to produce relevant and necessary data.

In the first section, the necessary information for a very basic EM model is described. In the following sections, the most useful possible extensions to a simple model are described.

\section{Simple EM models}

EM fungi constitute a major sink of plant-fixed carbon in EM forests. Up to now, most EM models focus on the fate of this belowground carbon $(\mathrm{C})$ flow, and the linked $\mathrm{N}$ flow to the host plant, and do not include possible interactions with other soil processes. In this section, we describe the fundamental basics

Received 3 December 2013. Accepted 2 March 2014.

G. Deckmyn. Plant and Vegetation Ecology, University of Antwerp, Antwerpen, Belgium.

A. Meyer. Department of Biological and Environmental Sciences, University of Gothenburg, Göteborg, Sweden.

M.M. Smits. Centre for Environmental Sciences, Hasselt University, Diepenbeek, Belgium.

A. Ekblad. School of Science \& Technology, Örebro University, SE-701 82 Örebro, Sweden.

T. Grebenc and H. Kraigher. Slovenian Forestry Institute, SI-1000 Ljubljana, Slovenia.

A. Komarov. Institute of Physicochemical and Biological Problems in Soil Science, Russian Academy of Sciences, Puschino, Moscow Region, Russia.

Corresponding author: G. Deckmyn (e-mail: gaby.deckmyn@uantwerpen.be). 
Fig. 1. Simple flow chart of $C$ and nutrients ( $P$ and $N$ ) between soil, plant, and ectomycorrhizal (EM) fungi.

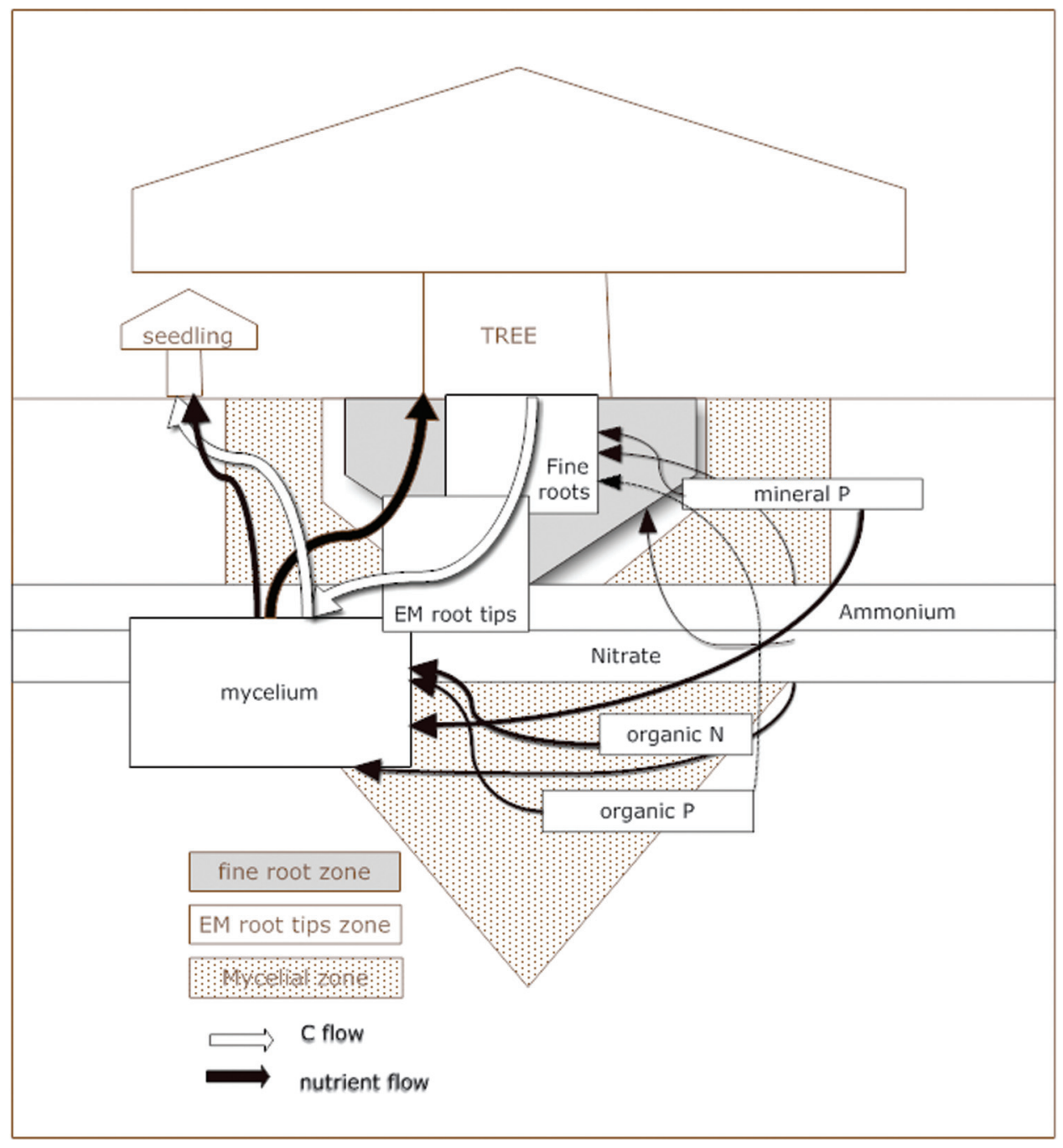

and appropriate parameter values of the role of EM biomass in the belowground $\mathrm{C}$ and $\mathrm{N}$ dynamics (see Fig. 1). An overview of existing simple models is included. Estimated parameter values can be found in Table 1.

\subsection{Basic values: pool size, growth, turnover, and respiration}

The first question concerns the size of the fungal biomass belonging to the mycorrhizal pool. This pool comprises fungal tissues in EM root tips and extramatrical mycelium (EMM), formed predominantly by differently organized and structured single hyphae, rhizomorphs, and sclerotia; in hypogeus fungi, fruit bodies can also be considered. Most published values concern only the EMM (see also section 1.3). Högberg and Högberg (2002) estimate (girdling experiment) that $32 \%$ of the soil microbial biomass in a Scots pine (Pinus sylvestris L.) forest was contributed by EMM. This contribution was calculated to be equivalent to $145 \mathrm{~kg} \cdot \mathrm{ha}^{-1}$, corresponding to $58 \mathrm{~kg} \mathrm{C} \cdot \mathrm{ha}^{-1}$. It is not possible to fully differentiate between saprotrophic and EM mycelia in the field. Estimations are that around 50\% of mycelia in boreal forests are from EM fungi, but this fraction is highly variable (Bååth et al. 2004). Furthermore, it is difficult to differentiate between live and dead mycelium. Wallander et al. (2004) used a specific phospholipid fatty acid $(18: 2 \omega 6,9)$ as proxy for living fungal biomass, and its degradation in incubated soil samples was used as a measure of EM fungal biomass. Total EM biomass estimates by this method ranged from
$4.8 \times 10^{3} \mathrm{~kg} \cdot \mathrm{ha}^{-1}$ (spruce) to $5.8 \times 10^{3} \mathrm{~kg} \cdot \mathrm{ha}^{-1}$ (mixed oak-spruce). Nilsson and Wallander (2003) found 120-800 kg EMM.ha- ${ }^{-1}$ (depending on nutrient availability and season), while Hagerberg et al. (2003) reported $110 \mathrm{~kg} \cdot \mathrm{ha}^{-1}$ for EMM in the upper $5 \mathrm{~cm}$. EMM has often been expressed in length units. For example, Jones et al. (1990) reported values from 20 to $50 \mathrm{~m} \cdot \mathrm{g}^{-1}$, with reported conversion factors ranging from 1 to $3 \times 10^{5} \mathrm{~m} \cdot \mathrm{g}^{-1}$ (Wallander et al. 2004) to $8.3 \times 10^{5} \mathrm{~m} \cdot \mathrm{g}^{-1}$ (Hunt and Fogel 1983) to convert length to biomass or from 2.75 (Stahl et al. 1995) to $4.12 \mathrm{mg} \cdot \mathrm{m}^{-1}$ to convert length to C content values (Miller et al. 1995). Interestingly, the EM fungal biomass followed a similar trend as the fine root distribution in these sites, which could be an incentive for modeling purposes (Wallander et al. 2004; Thelin et al. 2002). In fungal mats, sometimes found at the boundary between the organic soil and the mineral soil, up to $600 \mathrm{~km} \cdot \mathrm{g} \mathrm{soil}{ }^{-1}$ has been measured (Ingham et al. 1991).

The standing pool of EMM biomass is the product of hyphal growth and mortality. Under laboratory conditions, growth rates of the mycelial front of up to $8 \mathrm{~mm} \cdot$ day $^{-1}$ (Donnelly et al. 2004), but typically 2-4 mm.day ${ }^{-1}$ (Read 1992), have been reported. The growth rate of the mycelial front in forest soils is unknown, but estimates from the radial spread of fungal genets of Suillus bovinus (L.) Roussel (1806) averaged about $0.7 \mathrm{~mm} \cdot \mathrm{day}^{-1}$, as estimated by Ekblad et al. (2013) from data in Dahlberg and Stenlid (1994). For soil-scale modeling purposes, it is more useful to express EM fungal growth as kilograms per hectare of soil $\left(\mathrm{kg} \cdot \mathrm{ha}^{-2}\right)$. Over the last 
Table 1. Basic parameter values for ectomycorrhizal (EM) models.

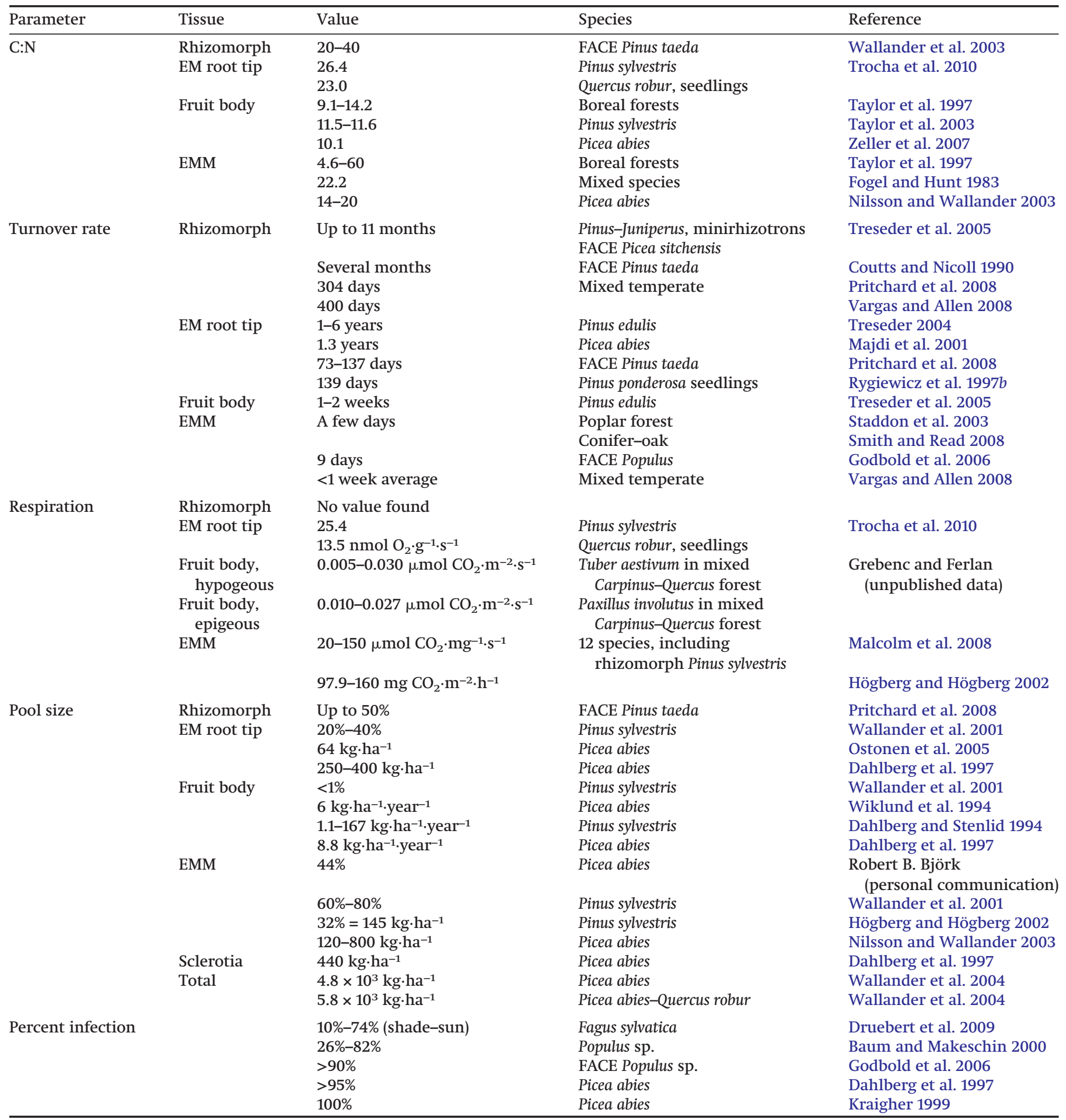

Note: C:N, ratio of carbon to nitrogen; FACE, free-air $\mathrm{CO}_{2}$ enrichment; EMM, extramatrical mycelium.

decade, it has become popular to use mycelial in-growth bags to estimate the production of EMM (Wallander et al. 2001; for a recent compilation of studies using this technique, see Ekblad et al. 2013; for a review of this and other methods to estimate the production and turnover of EMM, see Wallander et al. 2013). One advantage with in-growth bags is that they are colonized mainly by mycorrhizal fungi and the contribution of saprotrophs seems to be small (Wallander et al. 2001; Kjøller 2006; Parrent and Vilgalys 2007; Hedh et al. 2008), which is an advantage compared with the traditionally used mycelium length estimates (e.g.,
Söderström 1979; Vogt et al. 1982; Fogel and Hunt 1983). Wallander et al. (2004) measured $590 \mathrm{~kg} \cdot \mathrm{ha}^{-1} \cdot \mathrm{year}^{-1}$ in spruce stands and $420 \mathrm{~kg} \cdot \mathrm{ha}^{-1} \cdot$ year $^{-1}$ in mixed spruce-oak stands. In a recent survey of EMM production estimates from $\sim 140$ temperate forest sites, an yearly average production of $160 \mathrm{~kg}$ dry mass $\cdot \mathrm{ha}^{-1} \cdot \mathrm{year}^{-1}$ in the upper $10 \mathrm{~cm}$ soil (range of 20 to $980 \mathrm{~kg} \cdot \mathrm{ha}^{-1} \cdot \mathrm{year}^{-1}$ ) was estimated (Ekblad et al. 2013). These values should probably be at least doubled for a whole soil profile, based on the very few studies that report production estimates from more than one soil depth (Rosling et al. 2003; Egerton-Warburton et al. 2003). 
Turnover of mycelia has mostly been measured on arbuscular mycorrhizae (e.g., Fitter 2006; Rillig et al. 2007; Staddon et al. 2003). Only few measurements are available from EM. The turnover rate of the EMM depends on the ratio between fine mycelium and rhizomorphs (see section 1.2). The $C$ and nutrient content of EM tissues should be known to link the dynamics of fungal tissues with belowground cycles of carbon and nutrients. The C-to-N ratio (C:N) of EM mycelium in forest soils is typically lower than of the host plant, values around 15-22 (Nilsson and Wallander 2003; Boström et al. 2007) are generally reported. Besides C and N, P is an important component: C:N of 10 (or $89.2 \mathrm{mg} \cdot \mathrm{g}^{-1}$ ) and C-to-P ratio (C:P) of 50 (or $17.8 \mathrm{mg} \cdot \mathrm{g}^{-1}$ ) are found in literature for AM fungi (Landis and Fraser 2007). For EM mycelia, P from $1.7 \mathrm{mg} \cdot \mathrm{g}^{-1}$ under P-limited conditions up to $13 \mathrm{mg} \cdot \mathrm{g}^{-1}$ was measured (Cairney and Smith 1992), equivalent to a C:P of 558 to 71. For rhizomorphs, a $\mathrm{P}$ content of $0.5-0.6 \mathrm{mg} \cdot \mathrm{g}^{-1}$ was determined by Wallander et al. (2003).

An EM carbon balance should also include a respiration rate. Both isotopic analysis (Trumbore 1997, 2006) and field manipulation studies (Högberg et al. 2001) demonstrate that over a growing season, less than half of the total forest soil respiration is accounted for by the breakdown of soil organic matter (SOM). Belowground allocation of photosynthate products and rapid ( $<1$ week; Ekblad and Högberg 2001; Ekblad et al. 2005) transition into $\mathrm{CO}_{2}$ is responsible for the other half of total soil respiration (see also Högberg and Read 2006). EM fungi probably play an important role in regulating this part of the respiration, because of (i) higher respiration rates of fungal tissues compared with plant roots (Malcolm et al. 2008), (ii) high turnover rate of fine mycelium (Staddon et al. 2003; Smith and Read 2008; Godbold et al. 2006), and (iii) exudation of easily degraded organic molecules (Högberg and Högberg 2002; Johansson et al. 2009). In situ estimations of the contribution of EM fungi to total soil respiration range from $18 \%$ in an oak forest to $25 \%$ in a young pine forest (Heinemeyer et al. 2007, 2011). Yi et al. (2007) reported that $20 \%-$ $37 \%$ of soil respiration in a subtropical forest is mycorrhizal. Phillips et al. (2012) found a 16\% increase in soil respiration at dense mats of EM fungal mycelium, compared with neighbouring soil, and calculated that EM respiration represented $40 \%$ of rhizosphere respiration. Thus, also from a modeling perspective, the understanding of the regulation of fungal respiration is of major importance (Hughes et al. 2008). For fungi in general, maintenance respiration rates of $0.06-0.12 \mathrm{~g} \cdot \mathrm{g}^{-1} \cdot \mathrm{h}^{-1}$ have been reported (Lynch and Harper 1974). Malcolm et al. (2008) reported between 20 and $150 \mu \mathrm{mol} \mathrm{CO} \cdot \mathrm{mg}^{-1} \cdot \mathrm{s}^{-1}$ for EM fungi.

A relatively large number of studies include the colonization by EM as percent infected or colonized fine roots, as this is relatively easy to measure (values ranging from $10 \%-100 \%$; for a review, see Read et al. 2004). Infection rates are species- and site-dependent and sometimes influenced by management, nutrients, and (or) $\mathrm{CO}_{2}$. However, the infection percentage is not clearly related to the associated EM biomass or to functional or taxonomic diversity (Rosling et al. 2003).

\subsection{Basic $C$ and nutrient exchange}

Besides the obvious flow of $C$ from the host plant to the $\mathrm{EM}$, the nutrients studied most frequently with regard to their impact on ectomycorrhiza are $\mathrm{N}$ and $\mathrm{P}$; therefore, we will focus on these three in the following paragraphs.

\subsubsection{C exchange}

Although it is assumed that ectomycorrhizal fungi have some capacity to degrade complex organic compounds (Smith and Read 2008; Durall et al. 1994; Hobbie and Hobbie 2006; Rineau et al. 2012; see also section 2.1), the majority of species seem to rely on the host plants' C supplies to a very high degree (Nehls 2008; Courty et al. 2010).
From field and laboratory studies, it is estimated that between $5 \%$ and $50 \%$ of the plant's recent photoassimilates can be transferred to the EM fungi (Leake et al. 2004; Jones et al. 2009; Leake 2007, 10\%-30\%; Simard et al. 2002, 10\%-50\%). C transfer is complex, and both regulated and unregulated transfer of recent photoassimilates and stored $\mathrm{C}$ to the EM have been described (Druebert et al. 2009; Pena et al. 2010, see chapter 4). At an ecosystem level, the published estimates of $\mathrm{C}$ allocation into belowground EM (EM root tips, EMM, and fruit bodies) varied from 0\%-20\% (Hobbie and Hobbie 2006) to $12.5 \%-15 \%$ (Smith and Read 2008) of the net primary production (NPP) of a forest stand. In a recent review, Ekblad et al. (2013) estimated an overall average of $7.2 \%$ of NPP allocated to EM as a realistic value, based on the current knowledge of EMM growth and turnover rates.

\subsubsection{N uptake}

In general, plant $\mathrm{N}$ uptake is improved by association with EM fungi through four possible mechanisms: (i) efficiency of the uptake mechanisms, (ii) exploration of bigger soil volume, (iii) uptake of organic forms (e.g., amino acids), and (iv) release of nutrients from nonplant available sources (e.g., complex organic matter). Potential uptake rates for EM have been determined under controlled conditions and were reviewed by Plassard et al. (1991). Their findings show high diversity in potential uptake rates as ammonium uptake ranged as much as $19-600 \mu \mathrm{mol} \cdot \mathrm{g}$ root tip ${ }^{-1} \cdot \mathrm{h}^{-1}$ between species. Nitrate uptake was estimated to be much lower (39-45 $\mu \mathrm{mol} \cdot \mathrm{g}$ root $\mathrm{tip}^{-1} \cdot \mathrm{h}^{-1}$ ) but could only be given for two species. In general, EM fungi are not necessarily more efficient in taking up mineral $\mathrm{N}$ compared with plant per unit surface area, but because of the high surface area (EM fungi are much thinner than fine roots), total uptake is higher. The increase in exploration area has been often shown, although it is highly speciesvariable (see section 2). Uptake of organic forms (amino acids) appears to be more common in EM fungi than in plant roots, but no estimates of rate have been published to our knowledge. Concerning the breakdown of complex organic compounds and the related release nutrients, especially P but also N (Finlay 2008; also see section 3 of this review), although important, this matter is too complex for inclusion in simple models. A more general approach, without focusing on the uptake mechanisms, was used by Bending and Read (1995), giving nutrient uptake rates from the fermentation horizon SOM as $0.7 \% \mathrm{~N} \cdot \mathrm{day}^{-1}$ (or 45-78 $\mu \mathrm{g} \cdot \mathrm{g} \mathrm{SOM}^{-1}$. day ${ }^{-1}$ ) above the mineralisation rate of the substrate (although these data are from an artificial microcosm).

\subsubsection{P uptake}

Even more for $\mathrm{P}$ than for $\mathrm{N}$, because of the lower mobility of $\mathrm{P}$, the extended foraging range and high surface area are very important in explaining increased $\mathrm{P}$ uptake by mycorrhizal trees (Hayman 1983; Harley and Smith 1983). P uptake has been studied extensively in AM, whereas only a few values for P uptake rates exist in literature for EM. Van Tichelen and Colpaert (2000) found 0.13-0.62 nmol.g EM root tip $\mathrm{p}^{-1} \cdot \mathrm{s}^{-1}$ in growth medium compared with $0.08 \mathrm{nmol} \cdot \mathrm{g}$ root tip $\mathrm{p}^{-1} \cdot \mathrm{s}^{-1}$ for nonmycorrhizal root tips. Cairney and Smith (1993) reported 11.5-24.7 $\mu \mathrm{mol} \cdot \mathrm{g} \mathrm{EM}^{-1} \cdot 16 \mathrm{~h}^{-1}$ in growth medium. For modeling purposes, it can be assumed that EM take up all available mineral P. Because of the high uptake efficiency of mineral $P$ and the low mobility in the soil, in a forest, $P$ is generally derived from organic compounds that are less available as a source of P to plants. Bending and Read (1995) gave $\mathrm{P}$ uptake rates from the fermented horizon SOM pool as $4.1 \mu \mathrm{g} \mathrm{P} \cdot \mathrm{g} \mathrm{SOM}^{-1}$.day ${ }^{-1}$, or $0.7 \%$ P.day ${ }^{-1}$. However, much uncertainty still exists about the $P$ sources available to EM (for a review, see Plassard and Dell 2010), so these rates will depend very much on the available SOM pools but can be quite high (60\%-70\% of organic P within 90 days; Plassard and Dell 2010). 


\subsubsection{Nutrient transfer to the host plant}

Uptake by the EM fungi is generally not the goal of the modeling exercise. More important is the transfer to the host plant. Global estimations of fungal contribution to plant $\mathrm{N}$ uptake range around 90\% (Hobbie and Hobbie 2008; van der Heijden et al. 2008); in a controlled experiment, Brandes et al. (1998) reported 70\%, but these rates differ probably between fungal species (Lang and Polle 2011). For P, even fewer studies exist, but estimates are similar to those of $\mathrm{N}$ contribution (e.g., Brandes et al. 1998: 73\%). Next to $\mathrm{N}$ and $\mathrm{P}$, fungi are known to also improve plant $\mathrm{Mg}, \mathrm{Ca}, \mathrm{K}, \mathrm{Zn}$, and Fe nutrition (Marschner and Dell 1994). The high transfer rates are a combination of increased exploitation area and enhanced uptake rate but are also explained by the envelopment of the fine roots with the fungal mantle so that direct fine root uptake is reduced by the EM. The impact of this root envelopment on root nutrient uptake is still not completely clarified. Direct root uptake without passage over the fungal plasma membrane is inhibited, as reviewed by Taylor and Alexander (2005), but selective passage of certain nutrients from the soil to the root is possible.

\subsection{EM structures}

From a modeling perspective, it can be useful to limit the EM fungal biomass to one carbon pool, but even simple models tend to include some differentiation between the different EM tissues as they are very different in terms of turnover time, respiration, and C:N (see values provided below and in Table 1). EM fungi show high morphological diversity (Agerer 1991, Agerer 1987-1993), but in general, the following tissues are recognized.

\subsubsection{EM root tip}

The EM root tip is the interface between the plant and the fungus. Fungal tissues envelop short lateral roots, and a net of hyphae (Hartig net) penetrate between epidermal and cortical root cells down to the endodermis. Because of the intergrowth of fungal and plant tissues, it is challenging to obtain parameter values for modeling this fraction of the EM biomass. However, values for complete EM root tips are often found in literature and can be used to estimate the fungal pool. For conversion of EM root tip dry mass to grams of fungal C, a correction factor of $0.5 \mathrm{~g} \mathrm{C} \cdot \mathrm{g}$ dry mass ${ }^{-1}$ has been used (Smith and Read 2008). Grebenc and Kraigher (2009) calculated 0.0083-0.0692 mg C.root tip ${ }^{-1}$, with an average value across the $20 \mathrm{EM}$ for European beech of $0.0169 \mathrm{mg}$ C.root tip ${ }^{-1}$. Dahlberg and Stenlid (1994) proposed 11\%$30 \%$, and Dahlberg et al. (1997) used a conversion factor from total fine root dry mass of 3\% (spruce) and $4.5 \%$ (Scots pine), whereas Ostonen and Löhmus (2003) suggested that 18\% is an appropriate value for conversion of EM root tip to fungal tissue, from which Ostonen et al. (2005) calculated fungal EM root tip biomass of $64 \mathrm{~kg} \cdot \mathrm{ha}^{-1}$ in a Norway spruce forest, while Dahlberg et al. (1997) reported $250-400 \mathrm{~kg} \cdot \mathrm{ha}^{-1}$. EM root tips have higher respiration rates (Marshall and Perry 1987; Rygewiecz and Andersen 1994; Martin and Stutz 2004) but decreased turnover rates and C:N (Langley and Bruce 2003) compared with nonmycorrhizal root tips.

\subsubsection{Fine mycelium and rhizomorphs}

The EMM comprises the EM fungal tissues extending from the root tip into the surrounding soil. This network is built up by a complex network of branching and joining of fungal cords (hyphae); these hyphae are sometimes bundled into thick strands (rhizomorphs). The structure and size of the extraradical mycelium varies widely between EM species and is well described for a great number of species (Agerer 2001). For modeling purposes, it is useful to divide the extraradical mycelium into fine mycelium and rhizomorphs. Rhizomorphs have a much higher longevity than the fine mycelium, a higher C:N (Vargas and Allen 2008; Pritchard et al. 2008), and probably lower respiration rates, al- though no published data were found. Unfortunately, most published data on EM biomass in the soil do not distinguish between fine mycelium and rhizomorphs (Ekblad et al. 2013). Also, measurements in the field are difficult and the results are variable. The few studies on rhizomorphs suggested that up to 50\% of EM C is located in rhizomorphs (Pritchard et al. 2008), but the amount is highly dependent on EM species (see section 2) and soil and host plant nutrient status (Pritchard et al. 2008). EMM respiration was determined by Malcolm et al. (2008) for 12 species and ranged between 20 and $150 \mu \mathrm{mol} \mathrm{CO} \cdot \mathrm{mg}$ dry $\mathrm{mass}^{-1} \cdot \mathrm{s}^{-1}$. Sclerotia, another extramatrical structure of several EM fungi (dense aggregation of hyphae), remain mostly unstudied in terms of their $\mathrm{C}$ budget contribution and longevity but may also be regarded as not an important parameter for separate soil C modeling. Dahlberg et al. (1997) measured $440 \mathrm{~kg}$ sclerotia $\cdot \mathrm{ha}^{-1}$ in a spruce forest, so pool size is quite large.

\subsubsection{Fruit bodies of EM fungi}

Fruit bodies form a small part of the total EM biomass $(0.6 \%$ of fungal C as found by Wallander et al. (2001); Smith and Read 2008) or $6 \mathrm{~kg} \cdot \mathrm{ha}^{-1} \cdot$ year $^{-1}$ (mean value during 1989-1993) (Wiklund et al. 1994). Together with their short longevity (weeks), fruit bodies are not an important pool for soil $\mathrm{C}$ modeling. Concerning the dynamics of fruit body formation, a review by Egli (2011) indicates a shortage of knowledge concerning environmental and management effects on fruit body productivity.

\subsection{Abiotic effects on EM growth}

Temperature and moisture content generally have direct effects on soil microbial growth and respiration. However, in the case of EM fungi, the effects are highly dependent on the interactions with the plant partner as temperature, drought, nutrients, and $\mathrm{CO}_{2}$ also mediate EM respiration through effects on the host plants (Staddon et al. 2002; Ekblad et al. 2013).

Temperature was frequently studied as a potential modifier of EM respiration rates. Whereas some studies reported an increase in respiration rate with increasing temperature (Bååth and Wallander 2003; Hawkes et al. 2008), other studies showed an acclimation effect (Malcolm et al. 2008) or no response (Moyano et al. 2007). Basic values of fungal respiration and growth responses to temperature were described by Pietikäinen et al. (2005) as square-root functions, and Malcolm et al. (2008) reported between 20 and $150 \mathrm{mmol} \mathrm{CO} \cdot \mathrm{mg}^{-1} \cdot \mathrm{s}^{-1}$ for most species with a $\mathrm{Q}_{10}$ of 1.67 to 2.56. On the other hand, according to Heinemeyer et al. (2007), EM hyphal respiration does not respond directly to changes in soil temperature but is rather regulated by the availability of carbohydrates. It was mainly the soil heterotrophic flux component that caused the commonly observed exponential relationship with temperature (Heinemeyer et al. 2007), which is in line with measurements on variations in total soil respiration (Ekblad et al. 2005) and an elevated $\mathrm{CO}_{2}$ experiment by Comstedt et al. (2006). An increase in plant $C$ tends to increase $C$ to the EM. Conditions in which root growth is promoted ( $\mathrm{N}$ or $\mathrm{P}$ deficiency, drought) increase relative allocation to the EM, but if the absolute values of $\mathrm{C}$ are significantly reduced, EM growth will also be significantly reduced. The plant photosynthesis and $C$ allocation to the EM fungus have a strong seasonal variation (Rygiewicz et al. 1997a; Nilsson and Wallander 2003). From the modeling point, a temperature-related higher fungal biomass for AM and EM fungi (Gavito et al. 2005; Hawkes et al. 2008; Heinemeyer et al. 2006), as well as a higher fungal colonization (Heinemeyer and Fitter 2004), should be noted.

Concerning the effects of moisture, EM hyphal respiration responded strongly to reductions in soil moisture (Heinemeyer et al. 2007). Because of hydraulic lift and the extended exploration area of the EMM, EM root tips may survive drought, though large changes in EM roots and rhizomorph biomass in response to 
Table 2. Existing mycorrhizal models and their main characteristics.

\begin{tabular}{|c|c|c|c|c|c|c|c|c|}
\hline Model & Type & Differentiation & $\begin{array}{l}\text { Ecosystem } \\
\text { model }\end{array}$ & Elements & $\begin{array}{l}\text { Effect on } \\
\text { aggregate }\end{array}$ & $\begin{array}{l}\text { Decomposition } \\
\text { of SOM }\end{array}$ & CMN & $\begin{array}{l}\text { Turnover } \\
\text { rate }\end{array}$ \\
\hline ANAFORE, Deckmyn et al. 2011 & EM & None & Yes & $\mathrm{C}, \mathrm{N}$ & Yes & Yes & No & \\
\hline Deressa and Schenk 2008 & AM & AMc & No & $\mathrm{P}$ & No & No & No & No \\
\hline Jolicoeur et al. 2002 & $\mathrm{AM}$ & AMc & No & $\mathrm{P}$ & No & No & No & No \\
\hline Landis and Fraser 2007 & $\mathrm{AM}$ & Arbuscules, AMc & Yes & $\mathrm{C}, \mathrm{N}, \mathrm{P}$ & No & No & No & Yes \\
\hline $\begin{array}{l}\text { MoBilE + Mycofon, } \\
\text { Meyer et al. 2010, } 2012\end{array}$ & EM & EMc-HN & No or yes & $\mathrm{C}, \mathrm{N}$ & No & No & No & Yes \\
\hline Ruotsalainen et al. 2002 & All & None & No & $\mathrm{P}$ & No & No & No & \\
\hline $\begin{array}{l}\text { Schnepf and Roose 2006, } \\
\text { Schnepf et al. } 2008\end{array}$ & AM patterns & AMc & No & $\mathrm{P}$ & No & No & No & Yes \\
\hline Staddon 1998 & $\mathrm{AM}$ & Intra-extra radical & Yes & $\mathrm{C}$ & No & No & No & No \\
\hline
\end{tabular}

drought have been measured (Pritchard et al. 2008). However, the sensitivity of the EMM to drought possibly varies considerably between different exploration types of fungi, and rhizomorps may also grow rapidly at very low soil water content (Vargas and Allen 2008).

The changing (increasing) atmospheric $\mathrm{CO}_{2}$ concentrations have mainly indirect effect and, from field experiments on EM colonization and EMM production, seem to be insignificant in most cases, except for rhizomorphs (Pritchard et al. 2008; Rygiewicz et al. 1997b). Besides this, Finzi et al. (2007) noted that effects were mostly plantmediated and led to an increase in fungal biomass due to higher photosynthesis and higher belowground C allocation (e.g., Gavito et al. 2000; Treseder 2004; Wiemken et al. 2001). Indications for any different response are too uncertain and scarce to assume differences for a modeling approach.

\subsection{Modeling approaches and implications}

\subsubsection{Existing models}

Several models that involve mycorrhizal symbioses have been developed so far and can be distinguished between purely AM and EM models and models that have no clear distinction in mycorrhizal type (Table 2). The majority of existing models focus on AM, as they are considered important in P nutrition of agricultural plants (Collins-Johnson et al. 2006; Schnepf and Roose 2006; Deressa and Schenk 2008). These models are mostly stand-alone models that only consider a mycorrhized root and the fungi and concentrate on the fungal $P$ uptake dynamics and its contribution to the plant P nutrition (Deressa and Schenk 2008; Jolicoeur et al. 2002; Schnepf et al. 2008; Schnepf and Roose 2006). In contrast, the mycorrhizal $\mathrm{P}$ uptake route has been widely neglected in EM models. Incorporating P uptake concepts of the AM models into EM models could elucidate the possible role of EM in the plant uptake of this important nutrient. The increase in $\mathrm{N}$ levels (through pollution), together with increasing acidity, have been shown to shift forests from N-limited to P-limited (Gress et al. 2007). Inclusion of $P$ effects on forest growth is therefore becoming more relevant. It is possible that by simulating mineral uptake of P only, an overestimation of $\mathrm{P}$ limitation of tree growth is made, as mineral $\mathrm{P}$ content is very low in many soils. Even a model simply including organic P uptake (without explicit simulation of the EM fungi responsible) could improve the simulations.

AM models are generally a good starting point for simple EM models, but attention needs to be paid to some important differences: EM fungi are a more diverse group than AM fungi. All known species of AM-forming fungi are placed in the same phylum (Glomeromycota), are obligate mycorrhizal, and are thought to have one common symbiotic ancestor (Smith and Read 2008). EM fungi, on the other hand, are placed in several phyla (Basidiomycota, Ascomycota, and Zygomycota), and there is strong evidence that EM lifestyle has arisen at least 15 times independently from saprotrophic ancestors (Plett and Martin 2011). As a consequence, EM fungi show a huge variation in growth morphology, physiology, and EM-plant interactions, but all of the diversity remains neglected in models involving EM.

EM fungi are found more in $\mathrm{N}$-poor environments, so $\mathrm{N}$ uptake is important to the host trees. EM fungi appear to be more efficient in uptake of organic forms of $\mathrm{N}$ than $\mathrm{AM}$ fungi and, in most conditions, increase tree $\mathrm{N}$ uptake. In AM systems, generally, only mycorrhizal $\mathrm{P}$ uptake is beneficial to the host plants, while for $\mathrm{N}$ uptake, there is competition between fungi and host plant for mineral N. A detailed model emphasizing the increase in surface area by AM fungi as the most important factor in P uptake (which is highly efficient, i.e., uptake rate is not the limiting factor) has been developed by Schnepf and Roose (2006) and Schnepf et al. (2008)). If modified to include $\mathrm{N}$ uptake from organic pools, this model could be useful for EM systems.

Deckmyn et al. (2011) were the first to develop a full ecosystem model with explicit mycorrhiza consideration, though the EM are considered as a single pool (no differentiation in mycorrhizal roots and EMM). In their ANAFORE model, EM fungi also possess some degrading capacity of organic matter. Meyer et al. (2010) developed a simple plant-fungi feedback model that captures the main $\mathrm{C}$ and $\mathrm{N}$ exchange between a fungal $\mathrm{C}$ and $\mathrm{N}$ pool and a root $\mathrm{C}$ and $\mathrm{N}$ pool (Meyer et al. 2010, 2012). This is the only model that considers the effect of the hyphal mantle on plant nutrient uptake directly. Staddon (1998) simulated the $\mathrm{C}$ dynamics between a mycorrhized plant and the fungal community depending on ambient $\mathrm{CO}_{2}$ concentration and photosynthetic activity. His aim was to investigate the effect of elevated $\mathrm{CO}_{2}$ on fungal colonization. Also, Orwin et al. (2011) described mycorrhiza explicitly in the MySCaN model and linked them to the ecosystem $\mathrm{C}$ and $\mathrm{N}$ cycles. They found that explicit mycorrhiza implementation has considerable effects on simulated organic matter pools and degradation. They do not explicitly distinguish between AM and EM fungi.

\subsection{2. $C$ and nutrient flow between host plant and mycorrhiza}

In existing mycorrhizal models, different simple approaches have been used to simulate mycorrhizal growth, but all assume that the main C source is from the host plant. Orwin et al. (2011) defined a constant fraction of plant $C$ assimilates that is potentially available to the fungus and that is modified further by the intrinsic nutrient availability in the fungal and plant tissues (Orwin et al. 2011). In ANAFORE, a fraction of the $C$ allocated to the roots (modified by 
the water and nutrient availability) by the host plant yields similar results (Deckmyn et al. 2011). Both models increase allocation towards roots and EM when nutrients and (or) water is limiting. $\mathrm{N}$ uptake is simulated in a function of available pools (mineral and organic), and transfer to the host plant is unregulated and complete (EM fungi are simply simulated as "tubes" for $\mathrm{N}$ uptake, although some $\mathrm{N}$ is used for EM growth at a constant C:N).

In the model by Meyer et al. (2010, 2012), the maximum $C$ available for fungal growth is defined by a fraction of plant $\mathrm{C}$ assimilates, but the actual $\mathrm{C}$ demand of the fungus is determined by assuming that a certain ratio between root and fungal biomass exists to produce sufficient fungal biomass to reach the optimum (defined) degree of mycorrhization. The growth of the fungi is directly related to the $\mathrm{N}$ availability of the soil, as well as to the $\mathrm{N}$ supplies to the root delivered by the fungi.

$\mathrm{P}$ might very well be the more important nutrient but is not included in many ecosystem models. P uptake by EM is very efficient and includes uptake from organic pools not available to plants (Bolan 1991). Therefore, inclusion of this aspect, even in a simplified way, should influence ecosystem functioning significantly as P might be limiting in an increasing number of forest ecosystems as N pollution increases (Plassard and Dell 2010; Cumming 1996; Naples and Fisk 2010), although other authors suggest that N (Vitousek and Howarth 1991; Linder 1995) is generally still more limiting. Orwin et al. (2011) included P uptake from organic pools, which had previously been considered only in purely arbuscular models (e.g., Schnepf and Roose 2006; Schnepf et al. 2008), and the results clearly showed a significant impact on plant growth and soil $\mathrm{C}$ dynamics.

In conclusion, $\mathrm{N}$ transfer in existing models is implemented usually as a constant supply rate from the $\mathrm{N}$ and $\mathrm{P}$ taken up by the EM fungi. For an even more basic model, EM can be seen as simply enhancing plant $\mathrm{N}$ and $\mathrm{P}$ uptake from the soil by a constant factor and (or) by allowing a larger soil area or a constant fraction of organic $\mathrm{N}$ and $\mathrm{P}$ pools to be exploited. This does not necessarily imply explicit simulation of the EM but can be included into the fine root characteristics. Alternatively, another very simple way to model both $C$ and nutrient transfer would be to explicitly set an exchange rate, thus only allocating $\mathrm{C}$ to the EM if $\mathrm{N}$ and (or) $\mathrm{P}$ (or other nutrients) are provided. Although this is easy to implement and can yield good results locally and averaged over longer time, experimental data show that there is no constant exchange ratio (Jones and Smith 2004) and that C is possibly allocated to EM even when $\mathrm{N}$ and $\mathrm{P}$ are not immediately provided (see section 4.3.1, parasitical behavior of EM).

\subsubsection{Turnover and respiration}

Mycorrhizae turnover and respiration in models are generally described very simplistically. Fungal $C$ losses due to turnover can be defined as a certain fraction of $C$ that is lost per time unit. The easiest option to model mycorrhizal respiration is to set a certain fraction of fungal $C$ that is respired. Another possibility is to follow the concepts developed for plant root respiration, e.g., Thornley and Cannell (2000) as in Meyer et al. (2012), or to follow Arrhenius $\left(Q_{10}\right)$ temperature dependencies (Deckmyn et al. 2011), but a direct link to carbohydrate supply might be more realistic. One aspect that could easily be included in models is the recirculation (autolysis and reuse in production of new materials in the mycelium). However, it is unknown how high a proportion of the $\mathrm{N}$ and $\mathrm{P}$ (and $\mathrm{C}$ ) is reused. Either experimental data or a model analysis could elucidate whether this aspect is important for the soil nutrient balance.

From a modeling perspective, distinction is often made between live and dead fungal tissue (Deckmyn et al. 2011; Meyer et al. 2012), but field measurements cannot always make this distinction. Turnover rate from a modeling perspective is the death rate of a tissue that subsequently enters the litter pool and is decayed depending on recalcitrant proportion and C:N.

\subsubsection{EM structures}

In a very simple model, there is no separation into different fungal tissues. However, because their different functions and properties have a major impact on soil nutrient content and fungal nutrient uptake and turnover capacity, it is important to distinguish them in more advanced model approaches. Meyer et al. (2010) offered a parameter to divide EM biomass between the hyphal mantle and the extraradical mycelia, which are both characterized by different turnover rates. Rhizomorphs have not been implemented in any model yet but are clearly important due to their function as fast nutrient transport ways and extension structures, besides having a longer residence time and higher C:N. They can constitute a high fraction of the total fungal biomass and probably have a high impact on the total fungal $\mathrm{C}$ and $\mathrm{N}$ demand (Agerer 2001). Moreover, uptake of nutrients does not take place in the rhizomorphs, but at the tips of individual hyphae in the fine mycelium and EM root tips.

\subsubsection{Fine root infection}

In AM models, percent infection has played a central role (assumed to be a good measure of the $C$ allocated to the AM), but this approach has been questioned (Allen 2001). In EM models, some models assume that all fine roots are infected and no size of the infected root system is simulated or do not explicitly simulate rate of infection (ANAFORE, Deckmyn et al. 2011; MySCaN, Orwin et al. 2011).

Another option would be to use a species-specific maximum infection rate or to calculate infection from plant and EM growth rates (Meyer et al. 2010). To our knowledge, the Meyer model (Meyer et al. 2010 ) is the only one to include feedback between the percent infection and root uptake and turnover characteristics. Thus, although infection is rather well documented based on the experimental data, in models, it is not evident how to use this information because of the lack of knowledge on the implications. In models that do not differentiate between EM tissues, inclusion of percent infection is of little value. It is also important to note that in many ecosystems, $100 \%$ infection rate is found (Kraigher 1999).

Assuming that EM fungi are simulated as a single pool in the simplest model, they can be associated with trees of different species and ages at the same time. It could be effective and more realistic to simulate one EM pool with different associations to different tree species (allocating more nutrients to the species that has the highest infection) instead of simulating an EM pool for every tree species. One way to distribute the nutrient and C fluxes over the EM pools is to add all $\mathrm{C}$ available from the plants into a single pool. For the $\mathrm{P}$ and $\mathrm{N}$ taken up by the EM in surplus of the growth of the EM itself (depending on a maximum growth rate + available $\mathrm{C}, \mathrm{N}$, and $\mathrm{P}$ ), a simple rule linked to the mycorrhization degree of each tree or tree category (this can be the weight of mycorrhized fine roots per tree) seems the most obvious. This implies simulating the degree of mycorrhization, which is included so far only in the plant-scale models (Meyer et al. 2012), not in the forest-scale models (Deckmyn et al. 2011), as a function of allocated $\mathrm{C}$ and fine root surface area. For the simplest model, a species-dependent constant percent mycorrhization could be a reasonable assumption. Of course, if EM fungi are not explicitly simulated but only as part of the fine roots of each species, these issues do not need to be considered.

\subsubsection{Sensitivity to changes in environmental factors}

Most environmental indirect effects (through the host plants) are more important and better understood than direct effects. Even the simplest EM models should simulate the link between $C$ available from the host plant and EM growth. The relationship 
between the decrease in fungal abundance and biomass and the increase in soil $\mathrm{N}$ availability has been confirmed in a high number of published reports (see above), though infection rate is often $100 \%$, even under high N availability. Most models (Deckmyn et al. 2011; Meyer et al. 2010, 2012; Orwin et al. 2011) include either a direct or indirect mechanism leading to a reduction in plant $\mathrm{C}$ allocation into fungal biomass when $\mathrm{N}$ and (or) $\mathrm{P}$ are not limiting.

Effects of climatic factors such as temperature and soil moisture on fungal growth have so far been treated mainly as plant-mediated (effects through the changes in available $C$ ), but direct effects of such factors on respiration (using response curves similar to those of the plant) have also been implemented. However, this assumption is subject to high uncertainty and simulated $\mathrm{C}$ and $\mathrm{N}$ fluxes might be changed considerably if response curves differ.

From a modeling perspective, the indirect effect of mycelia formation on water uptake is relatively simple to consider in ecosystem models and would be expressed by, e.g., a higher water uptake efficiency of mycelia compared with roots or a higher potential uptake area.

\subsubsection{Missing concepts}

From the data above, it is clear that relatively simple EM models can be implemented into forest ecosystem models using average values. Such models are able to deal with the uptake of nutrients from pools not accessible to plants (i.e., P from the organic layer) and simulate the interaction between host plants and EM dynamically depending on the most limiting factor ( $\mathrm{P}, \mathrm{N}$, energy). The following are some important limitations to such models:

- very large differences between different EM fungi, the use of one average set of parameters may not cover cases in which the community of EMs changes over time;

- simple models are focused mostly on the plant-EM interaction, ignoring the significant direct and indirect effects of the EM on the soil organic pools;

- the interaction between host plant and EM appears more complex (Högberg et al. 1999; Kohzu et al. 2000) and has been shown to vary seasonally, during forest development, etc.; many studies have been performed to elucidate this relationship.

In the following sections, each of these aspects is further described.

\section{How to overcome large species and functional diversity in EM}

Although it can be tempting to simulate a single, unchanging, pool of EM fungi from a modeling perspective, there are several publications that suggest that this might not be adequate to catch the full diversity of EM effects in ecosystems. In contrast to AM, where about 200 fungi species infect about 200000 different plant species, in EM, roughly $25000 \mathrm{EM}$ species connect to ca. 8000 plant species (Rinaldi et al. 2008). Cairney (1999) reviewed a number of physiological characteristics of different EM species, but the number and taxonomic, structural, and functional diversity of EM species are far too high to attempt simulating them separately. Besides this, for the majority of EM fungi, very little is known about their biology, physiology, growing demands, and environmental limits, with commercial truffles such as the Périgord black truffle (Tuber melanosporum Vittad.) as a rare exception. Agerer (2001) introduced the concept of exploration types based on the large differences in morphology of the EMM, which may represent a promising grouping of the high EM diversity into a manageable number of classes applicable in EM and forest ecosystem modeling.

The categorization into types is based on the amount of EMM formed, the occurrence of more or less differentiated rhizomorphs, and also how far the extramatrical hyphae are reaching from the mycorrhizal root tip. The ectomycorrhizal mantle itself does not have a large contact area with the soil, so the emanating hyphae and rhizomorphs determine the volume of exploited soil (Read 1992; Smith and Read 2008). There appears to be a relationship between distance and the internal differentiation of rhizomorphs, the farthest reaching types being the most differentiated. Smith and Read (2008) and Kammerbauer et al. (1989) showed a clear relationship between the extent of rhizomorph organization and transport rates of phosphate therein. Besides this, rhizomorphs and rhizomorphs bearing EM have been shown to have a slower turnover compared with single hyphae (Pritchard et al. 2008; Vargas and Allen 2008). Five main exploration types have been distinguished with different putative ecological roles, each of which represents a distinct foraging strategy (Agerer 2001):

1. contact exploration type - EM tips and emanating hyphae, when present, are in close contact with the surrounding substrates (Brand 1991) enabling EM to successfully explore the substrate in their close vicinity;

2. short-distance exploration type - characterized by a voluminous envelope of emanating hyphae from the mantle, but rhizomorphs are not formed;

3. medium-distance exploration type - forms rhizomorphs and can be divided into three subtypes with respect to rhizomorphal features: $(a)$ fringe, $(b)$ mat, and $(c)$ smooth medium distance type:

(a) fringe medium-distance exploration type - forms fans of emanating hyphae and rhizomorphs, which ramify and interconnect; rhizomorph surfaces are hairy and form emanating hyphae with extended contact;

(b) mat medium-distance exploration type - forms undifferentiated or, at most, slightly differentiated rhizomorphs, thus individual mycorrhizae have only a rather limited range of exploration;

(c) smooth medium-distance exploration type - EM mantles appear rather smooth with almost no, or only a few, emanating hyphae; rhizomorphs belong to the type $\mathrm{B}$ (Agerer 1987-1993) and are internally undifferentiated or slightly differentiated or, very infrequently, with a central core of thick hyphae;

4. long-distance exploration type - characterized by rather smooth ectomycorrhizae with few but highly differentiated rhizomorphs that can be well over $>20 \mathrm{~cm}$ long;

5. pickaback ET - a combination of two EM fungi that, from the outer morphology, would be sorted into contact or smooth medium-distance exploration types (Agerer 2001), one of which can grow within rhizomorphs and (or) mantles of another EM.

Relevant parameters for each type can be found in Table 3.

So far, several environmental changes have caused shifts in the EM community through differences in rhizomorph characters and consequently in exploration type presence and abundance. $\mathrm{N}$ and $\mathrm{P}$ availability influences EM morphotype, as has been shown by Baum and Makeschin (2000) where fertilization reduced the number of rhizomorph-forming EM. Changes in temperature are also known to lead to shifts in EM composition, as do increased ambient ozone (Matyssek et al. 2010) and antiozonant chemicals (Katanić et al. 2013). Deslippe et al. (2011) found increases in hydrophobic hyphae and longer range, rhizomorph-forming EM types under warming. Simulated grazing experiments show that reduction in the carbon supply is affecting the EM community such that contact and short-distance exploration types increase, whereas the rhizomorph formers decrease in abundance (Barto and Rillig 2010). These shifts can be significant and might lead to considerable changes in the ecosystem $\mathrm{C}$ and $\mathrm{N}$ cycling pattern. 


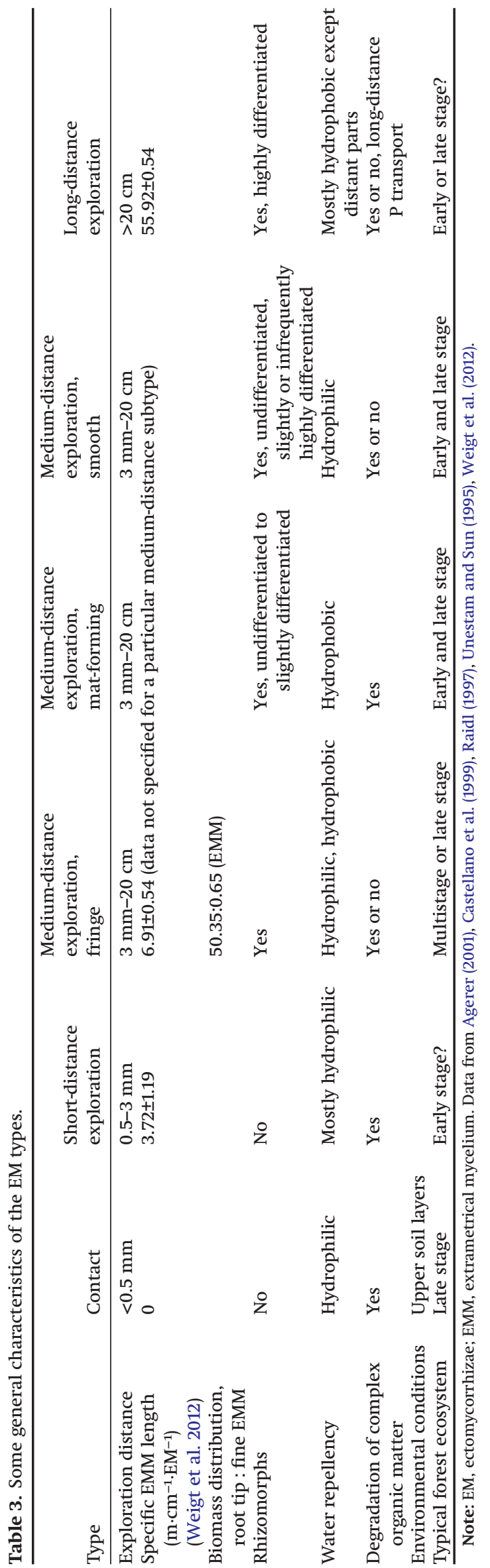

It might be questioned if the role of fungal diversity is of major importance in old established forest ecosystems where negative effects of certain species might be compensated by others. Fungal diversity could play a major role though when ecosystems are disturbed, e.g., after logging or due to acid rain. Kowalski et al. (1990) found that after being exposed to acid rain, the initial EM community of a mixed stand vanished and was replaced by acidtolerant EM species, which were smaller in diversity and formed only a thin sheath around root tips. These observed changes are likely to have decisive consequences for plant physiological and phytopathological functions.

\subsection{Model implications}

From a forest-modeling perspective, simulating the different EM taxa is clearly too complex. Modeling the exploration types is a useful intermediate step, as it allows simulation of different behaviors and groups all of the EM diversity into only five (seven) different groups (modeling pools). Simulation of one EM pool with parameters for the exploration type and rhizomorph formation is possible, but a more complex model with competing ecotypes might yield new insights. This requires a clear link between the ecotypes and their characteristics.

At the moment, several parameters of different exploration types were proposed with possible implications in modeling EM (Weigt et al. 2012). Specific EMM length and exploration distance may serve as relevant measures for the potential distance occupied by a particular exploration type, whereas parameter-specific potential (actual) mycelial space occupation gives a potential (actual) space occupation (e.g., the complete hyphal depletion zone; Weigt et al. 2012).

For modeling purposes, it would be an advantage to define fungal communities with certain properties that associate with certain tree species or that are present under particular defined soil properties. The main difficulties are as follows:

- lack of understanding of the ecological significance of the exploration types;

- fungal species do not always form the same exploration type (although most species do), and in a given site, different types can co-exist;

- EM exploration type might change in response to environmental changes, i.e., the most competitive type under the given circumstances survives;

For AM fungi, a recent model study calculates the theoretical optimum number of symbiotic AM fungi in a grassland using asymptotic diminishing returns as a function of the number of symbionts (Veresoglou and Halley 2012); a similar approach could yield interesting results for EM fungi.

In conclusion, it might be possible to construct a model simulating a full range of EM, and the economics (cost benefits) can be calculated to predict which type of symbiosis emerges. It is clear, however, that at the moment, data are lacking and only a very theoretical approach (such as in the AM study of Veresoglou and Halley 2012) would be possible at short notice.

\section{Effects of mycorrhiza on nutrient pools and other microorganisms}

The net effect of EM on total soil C is a sum of interacting effects (Fig. 2). (1) EM fungi degrade SOM. (2) EM fungi compete with saprotrophic microorganisms for nutrients. As a consequence, the saprotrophic microorganisms can be suppressed, and this can reduce SOM degradation because the EM fungi degrade some compounds more slowly (the "Gadgil effect"). (3) On the other hand, the belowground allocation of plant energy fuels the activity of EM fungi and associated microorganisms, increasing SOM degradation of energy-poor SOM (priming effect). (4) Nutrients are immobilized into the EM tissue. (5) EM fungi form relatively 
Fig. 2. Effects of ectomycorrhizal (EM) fungi on soil organic matter (SOM).

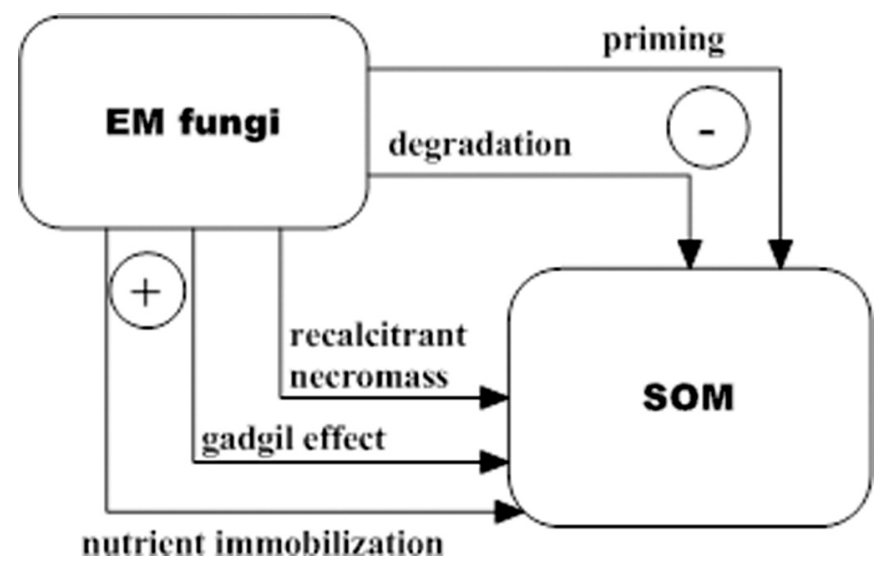

recalcitrant hyphae (cell walls can have a chitin content of up to $60 \%$; Langley and Hungate 2003) that enter the SOM pool after their death and could increase aggregate formation in the soil. However, Fernandez et al. (2012) questioned whether chitin is recalcitrant, so this obviously needs to be elucidated before it can be incorporated into models.

\subsection{Exploitation of organic versus mineral pools}

Only small fractions of soil $\mathrm{N}$ and $\mathrm{P}$ are available in mineral form. Most nutrients are stored in organic ( $\mathrm{N}$ and $\mathrm{P}$ ) form or as part of the crystal lattice of soil minerals ( $\mathrm{P}$ and base cations). EM fungi are highly efficient in uptake of mineral $\mathrm{N}$ and $\mathrm{P}$, but they are also involved in the mobilization of nutrients from less available pools. A number of studies have demonstrated the ability of EM fungi to break down all major classes of organic matter (e.g., Norkrans 1950; Trojanowski et al. 1984; Haselwandter et al. 1990; Read et al. 2004). A complication is that EM fungi show much variation in their abilities to utilize certain nutrient sources, e.g., some species do not show a significant growth on organic $\mathrm{N}$ forms, whereas other species can use amino acids as an energy source (Sangtiean and Smith 2002; Smith and Read 2008; Abuzinadah and Read 1986; Finlay et al. 1988, 1989; Koide et al. 2008). In vitro experiments show different results on the ligninand cellulose-degrading abilities of EM fungi (e.g., Bending and Read 1995; Colpaert and van Laere 1996; Colpaert et al. 1997; Martin et al. 2008; Nagendran et al. 2009). The role of EM fungi in the actual breakdown of complex organic matter as an energy source in the field has been questioned. It can be assumed that EM only degrade SOM as a C source when the supply from the host is limited (Högberg et al. 2001; Read and Perez-Moreno 2003). Courty et al. (2007) showed that before and during budbreak, EM fungi (Lactarius quietus (Fr.) Fr. (1838)) might be able to use SOM as a C source.

On the other hand, the availability of plant energy could enhance the degradation of SOM ("priming effect") in search for nutrients (Talbot et al. 2008), as has been demonstrated in non-EM plants (Dijkstra et al. 2006). Nutrients in degraded plant litter are protected by lignocellulose structures. A recent study showed a strong reduction of dissolved complex organic matter in the presence of an EM fungus, driven by a process involving the formation of radicals ("Fenton" reaction) (Rineau et al. 2012), which is suppressed by the absence of readily available energy (glucose) or the presence of ample inorganic N (Rineau et al. 2013). These results support the view that degradation of complex organic matter is an energy-limited process (Kuzyakov et al. 2009) and driven by nutrient ( $\mathrm{N}$ and (or) $\mathrm{P}$ ) demand.

\subsection{Competition with other microorganisms}

The Gadgil effect (Gadgil and Gadgil 1971), in which inclusion of EM fungi reduced the degradation of SOM due to competition with saprotrophs, has been described by several authors (Zeller et al. 2007). This does not need to contradict the enhanced SOM degradation by EM found in other studies. Several studies demonstrated a vertical differentiation of the microbial community in the soil profile (Dickie et al. 2002; Landeweert et al. 2003; Rosling et al. 2003; Lindahl et al. 2007). More than half of the EM root tips in a Swedish mixed coniferous forest were found in the mineral soil horizons (Rosling et al. 2003). Also, the majority of EM fungal biomass was found in the mineral soil horizons (Wallander et al. 2004). A detailed study of changes in C: $\mathrm{N}$ and ${ }^{15} \mathrm{~N}$ abundance with depth of the organic horizon revealed a distinctive shift from saprotrophic fungi in the coarse plant litter to EM fungi in the more decomposed litter and humus (Lindahl et al. 2007). From this spatial separation, the authors conclude that the process of organic nutrient mineralization is not dominated by saprotrophic fungi but by EM fungi and is ultimately fueled by the energy flux from the host trees into the EM hyphal network. Gadgil and Gadgil (1971) proposed that both EM and saprotrophic fungi compete for nutrients: saprotrophs win in energy-rich fresh litter but lose in deeper soil where $C$ is limiting. To date, there is no consensus as to what limits the growth of EM fungi $(C, N$, or P). Metaanalyses suggest that $\mathrm{EM}$ respond to $\mathrm{CO}_{2}$ with increased biomass and decreased $\mathrm{N}$ and $\mathrm{P}$ content, which suggests that EM fungi are still C-limited (Treseder 2004), but this has not been confirmed in field studies so far.

To further complicate matters, EM fungi support an associated community of helper bacteria (Garbaye 1994; Frey-Klett et al. 2007). These helper bacteria are thought to be involved in (i) nutrient mobilization from minerals and organic matter, (ii) fixation of atmospheric nitrogen, and (iii) protection of plants against root pathogens (Frey-Klett et al. 2007).

\subsection{SOM and micro- and macro-aggregate formation}

The flux of carbon into the belowground mycorrhizal network adds directly to the belowground organic matter pool when fungal hyphae die. Mycorrhizal fungi influence the formation or stabilization of soil at macroaggregate $(53-250 \mu \mathrm{m})$ and microaggregate $(<53 \mu \mathrm{m})$ scales with different mechanisms, which Rillig and Mummey (2006) differentiated into physical, biochemical, and biological processes. Biochemical effects include the release of mycelial products, including glomalin in AM fungi and polysaccharide polymers ("biofilms") in EM fungi. Biological effects include the influence of mycorrhizal mycelia on other microbial (e.g., bacterial) communities and fungal interactions with the soil food web. Physical effects include hyphal enmeshment of particles and microaggregates, altered water regimes (dry-wet cycles), alignment of particles, and exertion of pressure. Different aspects of the fungal mycelium may have different roles in these processes. Additionally, the fungal diversity is of highest importance, as EM fungal species differ in their effects on root hydraulic conductivity, influence differently root biomass, and possess diverse mycelium architecture (Rillig and Mummey 2006).

\subsection{Model implications}

Existing forest models generally do not include any effects of EM on SOM. N and P (if simulated) are often only taken up by the plants in the mineral form, which might induce an important overestimation of $\mathrm{P}$ and $\mathrm{N}$ limitation on tree growth. Inclusion of decay rates for the dead hyphal matter, possibly depending on C:N but generally lower than for dead plant matter, is relatively simple and should be feasible in most ecosystem models, though chitin decay should be better understood and parameterized first. Effects on aggregate formation are less evident to simulate, but if aggregate formation is included in a model, EM can be added as a 
linear modifier for this process (as in ANAFORE; Deckmyn et al. 2011).

Inclusion of interaction between soil microorganisms is possible if a fundamental change is taken from the popular view of decay rates being driven by the soil organic pools (modified by environmental factors) to a dynamic simulation of the soil microorganisms. One nice example is a modeling study by Banitz et al. (2011) on the effects of fungal networks on degradation by bacteria. With three or more pools of microorganisms with different requirements in $\mathrm{C}, \mathrm{N}$, and $\mathrm{P}$ and different efficiencies in decaying the soil $\mathrm{C}$ pools, a more realistic representation of the complex web of interactions between the decay rates and the organisms can be created. However, an intermediate solution in which the pool size of the microorganisms is a modifier for the decay rates of the soil organic pools could be an easier way to implement at least some of the effects described above.

Regarding organic matter degradation abilities of fungi, only in the ANAFORE (Deckmyn et al. 2011) and MySCaN (Orwin et al. 2011) models does EM have a capacity for litter degradation, which is about one-tenth of the capacity of simulated saprophytic fungi. The AM model of Schnepf and Roose (2006) also includes uptake of $\mathrm{P}$ and $\mathrm{N}$ from the organic litter layer, depending on the surface area of the AM and limited by a maximal uptake rate. Although these models simulate a direct link between EM biomass and SOM degradation rate in competition with saprotrophic fungi, it would be possible in a more simple model to attribute a constant fraction $(10 \%)$ of the SOM degradation to EM.

\section{Variability in host-fungi interaction}

\subsection{Factors influencing the symbiotic benefit: from mutualism to parasitism?}

EM are often considered symbiotic, with $C$ being exchanged only if nutrients are limiting. From a modeling perspective, a simple solution is to allocate a fixed percentage of NPP to the EM. However, these approaches do not cover the diversity of responses found in experiments.

Many studies have shown reduced $C$ transfer to EM fungi under nutrient-rich conditions (Nilsson and Wallander 2003; Jones et al. 1990). However, many cases have been reported in which the exchange between fungi and plant was not balanced and (temporary) negative effects on plant growth occurred (see e.g., Johnson et al. 1997). Whether the relation between fungi and plant turns parasitic seems to depend on a variety of factors such as plant age (Colpaert et al. 1996; Jones and Smith 2004), plant nutritional status (Correa et al. 2006, 2011), soil nutrient availability (Correa et al. 2011; Hammer et al. 2011), and environmental conditions such as drought (Davies et al. 1996) and C availability (light) (Bücking and Heyser 2003). These studies are mainly under laboratory conditions, and it appears that EM fungi in the field are almost always beneficial to the host. Johnson et al. (1997) recommended considering mycorrhiza as a principally mutualistic relationship that is interrupted by exceptional periods when the net plant costs exceed the benefits. Collins Johnson et al. (2010) found that locally adapted AM fungi are generally mutualistic, whereas artificial combinations used in laboratory experiments are not always.

Concerning the $C$ source, EM mainly use the new photosynthates, but some access to starch has also been shown (Druebert et al. 2009; Pena et al. 2010). The envelopment of the fine root with the fungal mantle, which constrains root nutrient uptake, implies that the plant is mainly accepting fungal supplies instead of controlling the symbiosis. However, there are indications that the plant indeed has some ability to regulate the $C$ transfer to the fungal partner from photosynthates. Nehls (2008) and Nehls et al. (2010) analysed the distribution of carbohydrate transporters in the root-fungal interface and concluded that there are several ways for the plant to down-regulate the C supply:
- the activity of photosynthesis can be regulated according to the fungal C sink strength;

- the sucrose transport into the apoplast can be controlled;

- the plant seems to have control over the magnitude of hydrolysis of sucroses to fungal-available hexoses; and

- root and fungi compete for hexoses in the apoplast, i.e., the root can redirect hexoses into root cells if fungal nutrient exporters are not active.

In a recent meta-analysis, Correa et al. (2012) concluded that $C$ allocation to the mycorrhizae is not the reason for the reported negative effects of EM on plant growth. They concluded that EM become parasitic when they reduce the plant nutrient uptake instead of increasing it. However, because of the complexity of the matter, we will explore the different environmental effects on the plant-fungi interaction by giving a short overview about the current state of research, by analysing the observed patterns with regard to their importance from a modeling perspective, and by considering the potential to include the observed patterns in ecosystem models.

\subsubsection{Effects of meteorological factors on plant-fungi interaction}

\subsubsection{Drought}

Increased allocation to mycorrhizae under drought conditions has been found in a study on EM fungi (Vargas and Allen 2008). This is a useful adaptation as several published studies indicated that ectomycorrhizal fungi can significantly contribute to drought resistance of plants and use several direct and indirect ways for that, e.g., the increased production of mycelia and lateral hyphae enhancing water uptake and the protection of root tips due to the hyphal coverage (see, e.g., Davies et al. 1996; Runion et al. 1997; Jany et al. 2003; di Pietro et al. 2007). Hydraulic redistribution and lift through mycelia and mycorrhizal plant roots should also be considered in this respect (Prieto et al. 2011; Smith and Read 2008). However, the magnitude of protection seems to vary considerably between species, and some particular droughtresistant fungal types such as, e.g., Cenococcum geophilum have been identified (di Pietro et al. 2007; Jany et al. 2003). However, some studies indicate that the plant limits its $C$ investments when a certain threshold is reached, e.g., as soon as the prospect of a benefit fades or the fungal $C$ requirements exceed the plant capacity (Volkmer 1999; Shi et al. 2002). Swaty et al. (2004), who studied plant drought stress symptoms and mycorrhizal colonization in a pine forests in USA, indicated that trees with intermediate drought stress showed a much higher fungal colonization (58\%) compared with trees under very high drought stress (29\%). Systems with seasonal droughts seem to be dominated by rhizomorph formers that are more drought-resistant.

\subsubsection{Light and temperature}

The effects of temperature and light changes cannot be fully separated as they both go along with a change in the available $\mathrm{C}$ resources. Light reductions, as well as reduction in temperature, lead to lower $C$ supply and can lead to proportional decreases in fungal $C$ supply. However, relative $C$ investment from the plant can temporarily increase if the nutrient supply and colonization remain constant. A reduction in EM fungi abundance has sometimes been observed (Son and Smith 1988; Johnson et al. 1997) so that the impact of light or temperature deficit probably depends on the plant vitality and its remaining $C$ sources (Johnson et al. 1997). In this respect, it is important that EM appear to have some access to stored $\mathrm{C}$ (starch) from the host plant during periods with insufficient supply of new photosynthates (Druebert et al. 2009; Pena et al. 2010).

The effect of higher temperatures has been observed to lead to both proportional increases in available $C$ and different respira- 
tion response curves of roots and fungi so that increased fungal $\mathrm{C}$ demand might lead to higher $\mathrm{C}$ losses for the plant (Bååth and Wallander 2003; Malcolm et al. 2008). These findings, however, were usually investigated in lab experiments, and the effects are not necessarily the same in established forests.

\subsubsection{Influence of nitrogen and phosphorus soil availability and plant nutrient status}

The nutrient status of the plant is the key determinant in carbon allocation between above- and below-ground parts of the plant (Ericsson 1995; Poorter and Nagel 2000). More specifically, plant limitations in the nutrients $\mathrm{N}, \mathrm{P}$, or $\mathrm{S}$ lead to increased investment belowground, whereas limitations of $\mathrm{K}, \mathrm{Mg}$, or $\mathrm{Mn}$ lead to reduced allocation belowground (Ericsson 1995). Addition of $\mathrm{P}$ or $\mathrm{N}$ often leads to a severe reduction in $\mathrm{EM}$ infection rate or growth (Nilsson and Wallander 2003; Jones et al. 1990). The same trends are also visible in the $C$ investment in the EM and arbuscular fungal biomass, the number of EM fungal fruiting bodies, and the degree of mycorrhization (for reviews, see Koide 1991; Wallenda and Kottke 1998; Wallander et al. 2011; Lilleskov et al. 2002; Nilsson et al. 2007; Frey et al. 2004; Parrent et al. 2006).

It is often observed under $\mathrm{N}$ shortage that $\mathrm{C}$ flow to the fungi is not reduced even when the plant shows some evidence of growth depressions (Johnson et al. 1997). This seems to be a result of high $\mathrm{N}$ retention in the fungal tissue rather than a $\mathrm{C}$ deficit in the plant (Correa et al. 2008, 2012). In an in vitro experiment by Colpaert et al. (1996), the fungal mycelia stored about $6 \%-16 \%$ of the total plant and fungal biomass but retained between $12 \%$ and $32 \%$ of the total N. Consequently, it can be assumed that the plant accepts not only high $C$ investments from the fungi but also parasitic appearances of the fungi if it suffers from nutrient shortage, i.e., that classic view of the mycorrhizal symbiosis might not apply at every point in time. In such cases, it can be seen as an investment in the future: in the long run, the mycorrhiza will have a mostly positive effect and investing in mycorrhizae to increase soil exploration is a strategy that increases the chance of survival on average. High soil $\mathrm{N}$ decreases the $\mathrm{C}$ allocated to EM in almost all studies, but the $\mathrm{P}$ availability may change that picture.

In an excellent review by Treseder (2004), it was shown that under high $\mathrm{P}$ levels, allocation to EM is more reduced than under high N levels. Deslippe et al. (2011) found no reduction in percent root mycorrhization with $\mathrm{N}$ fertilization. On the other hand, low $\mathrm{P}$ levels increase $\mathrm{C}$ allocation to EM even when plant growth is reduced. Laboratory experiments show that the effect of high $\mathrm{N}$ on EMM production was dependent on the $P$ availability such that low $\mathrm{P}$ stimulated EMM production irrespective of the $\mathrm{N}$ availability (Wallander and Nylund 1992; Ekblad et al. 1995). This suggests that $P$ availability is the dominant effect, which can be explained by the nonmobility of soil $\mathrm{P}$. Increasing the foraging range of the plant by EM is more important for $\mathrm{P}$ uptake than for $\mathrm{N}$ uptake.

\subsubsection{Influence of forest and tree age and seasonality on $C$ allocation to EM}

Plant age seems to be of major importance when assessing the benefit that the plant takes from the EM infection. Young saplings often show a growth depression or lower vitality than noninfected trees (Correa et al. 2006) in vitro or on forest establishment. However, in a mature forest, seedlings have been found to receive $C$ from the mycelial network (originating from mature trees) (see section 4.2.2). In accordance, it was found in field studies that trees make high $C$ investments into the EM network until canopy closure (at a forest age of about 20-30 years, depending on the forest). After that, $C$ investments seem to be lower because the mycelial network is fully established and soil exploration by mycelia production is complete, so the existing mycelia only has to be maintained (Wallander et al. 2010). Therefore, young trees very likely "accept" $\mathrm{C}$ investments, although no immediate benefit can be taken to establish a network that will benefit the whole ecosystem in the long term. Very little data concerning seasonality are available. Because EM use mainly fresh photosynthates (see above), highest growth rates are expected in summer. In autumn, $\mathrm{C}$ allocation to the roots is relatively higher but might be less accessible (storage $\mathrm{C}$ ). Also, relatively more ectomycorrhizal $\mathrm{C}$ is invested in fruiting bodies.

\subsection{Additional benefits in the mycorrhizal symbiosis}

Besides the direct reciprocal exchange of $C$ and nutrient between plants and the fungal symbionts, other plant benefits have also been reported. Increased protection of tree sapling against pathogens has been reported for both AM and EM. The infection of saplings with different mycorrhizal species has been shown to drastically reduce pathogen damage on saplings infected with Fusarium and Cylindrocladium (Chakravarty and Unestam 1987; Morin et al. 1999). Luo et al. (2009) report increased abiotic stress tolerance in EM-colonized trees explained by priming effects on stress-related signaling pathways. In addition, it has been shown that the fungal hyphal mantle that covers the root tips can significantly reduce root decomposition rates (Langley et al. 2006).

There is clear evidence that there is not only a direct nutrient and $C$ exchange between one ectomycorrhizal plant and the EM community, but in forest ecosystems, nutrients $(\mathrm{C}, \mathrm{N}, \mathrm{P})$ and water are exchanged between trees over extended "common mycorrhizal networks" (CMNs) (Arnebrandt et al. 1993; Simard et al. 1997, Brearley et al. 2007, Warren et al. 2008) according to source-sink relationships (Simard et al. 1997). These transfer processes imply that nutrients, $C$, and water shortages for single species can be overcome by these transfer strategies and that parasitic appearances between single fungi-tree connections may lose importance. The stability of a forest ecosystem is thus probably highly related to the tree-fungi-soil transfer of nutrients and water within CMNs.

Infection with EM does not lead to a stimulation of plant diversity (Lang and Polle 2011). On the contrary, poorly diverse patches within tropical forest areas have been reported and were deduced to be due to the infection of trees with EM (Connell and Lowman 1989).

\subsection{Modelling implications}

\subsubsection{C and nutrient exchange}

Although a lot of research and models have focused on this aspect of EM fungi, uncertainty remains quite high. Because the mechanisms of the control are unclear and too complex for forest-scale models, three main model strategies can be followed: (1) simplify to a constant C supply, (2) modify C supply as a function of nutrient availability or uptake, or (3) modify C supply following economic principles (optimal allocation).

\subsubsection{Models simulating $C$ supply as a function of soil or plant nutrient} status

From all of the evidence above, although there is evidence of changes in the relationship between the fungi and the plant, in most stable ecosystems and at a larger time scale, it seems reasonable to have $C$ supply to the EM as a constant fraction of photosynthesis (10\%-30\%; Staddon 1998). Although this is the simplest way to model the interaction, it does allow negative effects on growth if $\mathrm{N}$ and $\mathrm{P}$ are limiting plant growth. However, the oftenreported reduction in EM under high nutrient conditions is obviously not represented. Assuming forest nutrient conditions to be stable, this does not need to be a problem, and a simple model as described in (1) can be used.

In the more advanced models, modification of the $C$ fraction allocated to the EM as a function of nutrient availability and drought can be implemented, by either direct link to the $\mathrm{C}$ allo- 
cated to fine roots or linked to $\mathrm{N}$ or P shortage of the plant. In the latter, this implies plant control of the $C$ supply in a simple way.

For example, Orwin et al. (2011), Deckmyn et al. (2011), and Meyer et al. (2012) included mechanisms that lead to a reduction in EM fungal abundance with higher soil fertility. Orwin et al. (2011) used an indirect approach and reduced C allocation to the fungus with increasing $\mathrm{N}$ concentration in the plant, and Deckmyn et al. (2011) reduced C allocation to the root under high nutrient availability.

\subsubsection{Models simulating C supply following economic principles}

Several models include more explicit economic principles and trading concepts (for a review, see Johnson et al. 2007) and calculate an optimal ratio between shoot, plant root, and mycelial biomass (Fitter 2006; Ruotsalainen et al. 2002). Plant C is allocated to mycelia only in return for N and (or) P. Such models cannot simulate parasitical behavior but yield quite good results for longer term simulations (over several years), especially under stable conditions where an optimal host-fungi relationship can be expected. Neuhauser and Fargione (2004) used a predator-prey model to investigate the mutualistic-parasitic behavior of EM in a conceptual way. Economic models are extremely relevant to simulate the reduced $\mathrm{C}$ allocation to EM under high nutrient availability, especially for AM systems, where $\mathrm{N}$ and $\mathrm{P}$ fertilization is an important issue. For natural forest ecosystems and EM fungi, nutrient limitation is probably more frequent.

Along the same economic principles, but with the allocation blind to the actual pools (i.e., $\mathrm{C}$ is allocated to the mycelia under $\mathrm{P}$ shortage even though the fungi do not supply P), a better agreement with experimental data under P limitation is found (AM model of Landis and Fraser 2007). Other AM models, e.g., Collins Johnson et al. (2010), are based on the C, N, and P in the soil nonstructural pools to determine which is limiting. Economic principles allocate $C$ to the plant shoot when $C$ is limiting, to the root when $\mathrm{N}$ is limiting, and to the root and mycelia when $\mathrm{P}$ is limiting.

An intermediate approach was applied by Meyer et al. (2012) in which $C$ is allocated to the fungi aiming towards an optimal fungito-root ratio but is further regulated by the $\mathrm{N}$ transfer from the fungal symbiont. $\mathrm{C}$ delivery to the fungi would only be reduced considerably when less than $30 \%$ of the total plant uptake is covered by the fungal $\mathrm{N}$ supplies.

A compromise between the different modeling concepts might be to have a fixed minimal amount of $C$ (possibly starch) always available (parasitic under high nutrients) with no plant control, but to allow plant control on the percent photosynthates allocated to the EM depending on the nutritional status.

Furthermore, for $\mathrm{N}$ and $\mathrm{P}$ supply, other regulating mechanisms could apply. Published studies reported that with limiting P supplies, plants did not reduce their C allocation to EM (Wallander and Nylund 1992; Ekblad et al. 1995). Therefore, it might be more appropriate to use different response functions for $\mathrm{N}$ and $\mathrm{P}$ when insufficient $\mathrm{N}$ supply by the EM leads to reduced $\mathrm{C}$ delivery, whereas insufficient $\mathrm{P}$ does not or less so.

\subsubsection{Simulating drought and light effects}

The above-described effects of drought and light restriction on the plant-fungi interactions are hardly quantifiable and strongly linked to the local species composition and nutrient supply, i.e., resistance against drought or light deficit strongly depends on the respective intrinsic resilience of the plant and fungal species, on their $\mathrm{C}$ and $\mathrm{N}$ uptake efficiency, and on the overall combination of stressors. The modeling strategies described above can be used for light, temperature, and drought effects as well. Allocation is either a constant fraction of photosynthesis (and therefore lower under stress) or is influenced by root-shoot allocation (increase under drought) or follows economic trading concepts (optimized for every condition).

\subsubsection{Simulating the influence of community composition and plant-} fungal species

Consideration of fungal communities and their effect on plant vitality is related to the discussion on fungal ecotypes already mentioned above. For a simple mycorrhiza model, the consideration of different fungal species and their impact on nutrient exchange and plant vitality is too advanced and probably unnecessary when considering old established forest ecosystems that show a high degree of stability. However, when including either processes that alter ecosystem stability (e.g., acid rain, forest fires) or forest management activities (logging, fertilization), it might be necessary to simulate fungal communities as these might change which would have considerable impact on tree productivity. Including these in a more complex mycorrhiza model would require the existence of a community composition model that considers the respective characteristics of the described fungal species and their respective interaction with the plant. One step towards this is a study by Verbruggen et al. (2012), who tested how plant $\mathrm{C}$ allocation differs between high-quality and low-quality fungal partners and how this depends on the spatial structure. To our knowledge, no fungal community model exists so far, and model development is hampered by the difficulties in describing functional groups. As mentioned above, the definition of functional groups or exploration types of fungi associated with trees under specific environmental conditions could be a further step in this direction.

\subsubsection{Additional benefits}

Modelling the additional benefits such as pathogen protection has, to our knowledge, not yet been attempted. The main reason is that these observations are hardly quantifiable and especially not transferable into mathematic equations. The magnitude of the effect depends highly on composition and vitality of species so that high uncertainties would be produced. At the current state of research, it is this probably not advisable to implement these aspects.

Only one simple model has attempted to consider the formation of CMNs by focusing on the nutrient transfer between two plants (Dorneles et al. 2001, 2004). This model could be implemented into a more complex model by including the other EM functions. The model of Banitz et al. (2011) focused on the simulation of bacterial degradation but included the effect of dispersal along CMNs. So far, no inclusion into forest ecosystem models has been tested, which is probably explained by the high complexity of the system and the hampered transferability into ecosystem models. Also, it is unclear how important the relatively small fluxes of $\mathrm{C}$ between trees are at an ecosystem level. Next to the challenge of modeling different fungal ecotypes, the pattern of mycorrhization between different tree species is hardly representable. However, the formation of CMNs has important implications for the implementation of a mutualistic or parasitic mycorrhiza concept as the parasitic appearance of certain single species might not be of significance anymore, at least in the longterm perspective.

\section{Conclusion and summary: missing data and concepts}

Most current forest ecosystem models do not include the role of EM fungi, although some of the EM effects are implicitly built into the fine root parameters after optimization (increased uptake efficiencies and longevity of fine roots). If tree growth is the main emphasis, attributing some EM characteristics to the fine roots can improve model results, as almost all fine roots are associated with EM. The most important characteristics that can be included 
in this way are increased surface area and explored soil volume and the accessibility of nonmineral nutrient pools. Such models can simulate tree growth quite well, but this simplified approach will induce important errors in respect to soil $C$ dynamics. If the goal of the forest ecosystem model is to accurately simulate soil C dynamics, then the role of EM fungi should be included in a more detailed way.

Obviously, the focus of models to be included in ecosystem models will be on plant-EM interaction and effects on soil processes. Nonetheless, for specific applications, formation of sporocarps can be an important model output.

Although many EM parameters still lack accurate estimates, we believe that enough data and insight are available to allow inclusion of EM in soil models. More data are necessary concerning the following mechanisms:

- drought effects on EM through C allocation and hydraulic lift;

- plant control over symbiosis;

- EM species or ecotype changes in response to climate or management;

- balance between increasing soil stabilization and potential to degrade SOM using C from plants;

- recirculation (autolysis and reuse in production of new materials in the mycelium); and

- the fate of chitin in the soil: is it recalcitrant? What is the turnover rate?

A drawback of many reported studies is that they are conducted under artificial laboratory conditions that often do not reflect natural conditions and might in consequence lead to wrong assumptions when using the observations to construct model concepts. This is a general problem as these experiments are often much more progressing when aimed at developing model mechanisms because cause and consequence of observed relationships are much easier to identify compared with in field studies. The findings from lab experiments thus need to be considered with caution, and more field experiments are needed to either support or dismiss findings from lab observations.

However, of more concern is the lack of field data to evaluate EM models. Ideally, field measurements of forest soil C dynamics should include the following data:

- total EM biomass for different ecotypes, differentiated in rhizomorphs, hyphae, and EM root tips;

- turnover rates and respiration rates of hyphae and rhizomorphs in the field;

- standing EMM necromass and its turnover rate;

- C:N:P stochiometry of the different tissues; and

- average characteristics (extension, rhizomorph formation, capability of SOM degradation) of the ecotypes and the link between forest type and EM ecotype.

Besides difficulties in determining transfer rates, further information on environmental dependencies would be necessary to narrow model uncertainties. To fill some of these gaps, microcosm studies with ${ }^{15} \mathrm{~N}$ labeling and sequential harvesting under different environmental conditions could be an appropriate tool.

Concerning the existing EM models, the most useful improvements could be

- implementation of fungal diversity (either as diversity parameters of some kind of grouping (functional, taxonomic)) and subsequent parameterization and validation;

- implementation of effects on SOM including priming, competition with saprotrophs, and hyphal turnover; and

- improvement and validation of the different concepts of host-EM interaction.

In summary, experimental and modeling efforts need to be better tuned towards each other in the future. We sincerely hope that this paper will contribute to a better cooperation between modelers and experimentalists to the benefit of both communities. Nonetheless, inclusion of EM in forest and soil models, even with the current data limitations, can be an important improvement to model functioning and validity.

\section{Acknowledgements}

This manuscript is the result of the workshop meetings of COST action FP0803. G. Deckmyn is indepted to the BELSPO project ECORISK (contract SR/RI/06A) for funding.

\section{References}

Abuzinadah, R., and Read, D. 1986. The role of proteins in the nitrogen nutrition of ectomycorrhizal plants. I. Utilization of peptides and proteins by ectomycorrhizal fungi. New Phytol. 103: 481-493. doi:10.1111/j.1469-8137.1986. tb02886.x.

Agerer, R. 1987-1993. Colour atlas of ectomycorrhizae. 1st-7th editions. Einhorn Verlag, Schwäbisch Gmünd, Germany.

Agerer, R. 1991. Characterization of ectomycorrhiza. In Techniques for the study of mycorrhiza. Edited by J.R. Norris, D.J. Read, and A.K. Varma. Methods Microbiol. 23: 25-73.

Agerer, R. 2001. Exploration types of ectomycorrhizae. A proposal to classify ectomycorrhizal mycelial systems according to their patterns of differentiation and putative ecological importance. Mycorrhiza, 11: 107-114. doi:10.1007| s005720100108.

Allen, E.B. 2001. Modeling arbuscular mycorrhizal infection: is \% infection an appropriate variable? Mycorrhiza, 10: 255-258. doi:10.1007/s005720000081.

Arnebrandt, K., Ek, H., Finlay, R., and Söderström, B. 1993. Nitrogen translocation between Alnus glutinosa (L.) Gaertn. seedlings inoculated with Frankia sp. and Pinus contorta Dougl. ex Loud. seedlings connected by a common ectomycorrhizal mycelium rid. New Phytol. 124: 231-242. doi:10.1111/j.1469-8137.1993. tb03812.x.

Bååth, E., and Wallander, H. 2003. Soil and rhizosphere microorganisms have the same Q10 for respiration in a model system. Glob. Change Biol. 9(12): 1788-1791. doi:10.1046/j.1365-2486.2003.00692.x.

Bååth, E., Nilsson, L.O., Göransson, H., and Wallander, H. 2004. Can the extent of degradation of soil fungal mycelium during soil incubation be used to estimate ectomycorrhizal biomass in soil? Soil Biol. Biochem. 36: 2105-2109. doi:10.1016/j.soilbio.2004.06.004.

Banitz, T., Fetzer, I., Johst, K., Wick, L., Harms, H., and Frank, K. 2011. Assessing biodegradation benefits from dispersal networks. Ecol. Model. 22: 25522560. doi:10.1016/j.ecolmodel.2010.07.005.

Barto, E.K., and Rillig, M.C. 2010. Does herbivory really suppress mycorrhiza? A meta-analysis. J. Ecol. 98(4): 745-753. doi:10.1111/j.1365-2745.2010.01658.x.

Baum, C., and Makeschin, F. 2000. Effects of nitrogen and phosphorus fertilization on mycorrhizal formation of two poplar clones (Populus trichocarpa and P. tremula $\times$ tremuloides). J. Plant Nutr. Soil Sci. 163(5): 491-497. doi:10.1002/ 1522-2624(200010)163:5<491::AID-JPLN491>3.3.CO;2-V.

Bending, G.D., and Read, D.J. 1995. The structure and function of the vegetative mycelium of ectomycorrhizal plants. V. Foraging behaviour and translocation of nutrients from exploited litter. New Phytol. 130: 401-409. doi:10.1111/ j.1469-8137.1995.tb01834.x.

Bolan, N.S. 1991. A critical review of the role of mycorrhizal fungi in the uptake of phosphorus by plants. Plant Soil, 134: 189-207. doi:10.1007/BF00012037.

Boström, B., Comstedt, D., and Ekblad, A. 2007. Isotope fractionation and $\mathrm{C}^{13}$ enrichment in soil profiles during the decomposition of soil organic matter. Oecologia, 153(1): 89-98. doi:10.1007/s00442-007-0700-8.

Brand, F. 1991. Ektomykorrhizen an Fagus sylvatica. Charakterisierung und Identifizierung, ökologische Kennzeichnung und unsterile Kultivierung. Libri Botanici 2, IHW verlag, Eching, Germany.

Brandes, B., Godbold, D.L., Kuhn, A.J., and Jentschke, G. 1998. Nitrogen and phosphorus acquisition by the mycelium of the ectomycorrhizal fungus Paxillus involutus and its effect on host nutrition. New Phytol. 140(4): 735-743. doi:10.1046/j.1469-8137.1998.00313.x.

Brearley, F.Q., Scholes, J.D., Press, M.C., and Palfner, G. 2007. How does light and phosphorus fertilisation affect the growth and ectomycorrhizal community of two contrasting dipterocarp species? Plant Ecol. 192(2): 237-249. doi:10. 1007/s11258-007-9325-6.

Bücking, H., and Heyser, W. 2003. Uptake and transfer of nutrients in ectomycorrhizal associations: interactions between photosynthesis and phosphate nutrition. Mycorrhiza, 13(2): 59-68. doi:10.1007/s00572-002-0196-3.

Cairney, J.W.G. 1999. Intraspecific physiological variation: implications for understanding functional diversity in ectomycorrhizal fungi. Mycorrhiza, 9: 125-135. doi:10.1007/s005720050297.

Cairney, J.W.G., and Smith, S.E. 1992. Influence of intracellular phosphorus concentration on phosphate absorption by the ectomycorrhizal basidiomycete Pisolithus tinctorius. Mycol. Res. 96: 673-676.

Cairney, J.W.G., and Smith, S.E. 1993. Efflux of phosphate from the ectomycorrhizal basidiomycete Pisolithus tinctorius: general characteristics and the influ- 
ence of intracellular phosphorus concentration. Mycol. Res. 97: 1261-1266. doi:10.1016/S0953-7562(09)81295-1.

Castellano, M.A., Smith, J.E., O'Dell, T., Nugen, S., and Cazares, E. 1999. Handbook to strategy 1 fungal taxa from the Northwest Forest Plan. USDA Forest Service, Pacific Northwest Research Station, Portland, Oregon, Gen. Tech. Rep. PNW-GTR-476.

Chakravarty, P., and Unestam, T. 1987. Differential influence of ectomycorrhizae on plant growth and disease resistance in Pinus sylvestris seedlings. J. Phytopathol. 120: 104-120. doi:10.1111/j.1439-0434.1987.tb04423.x.

Collins Johnson, N., Hoeksema, J.D., Bever, J.D., Chaudhary, V.B., Gehring, C., Klironomos, J., Koide, R., Miller, R.M., and Moore, J. 2006. From Lilliput to Brobdingnag: extending models of mycorrhizal function across scales. BioScience, 56(11): 889-900. doi:10.1641/0006-3568(2006)56[889:FLTBEM]2.0. $\mathrm{CO} ; 2$.

Collins Johnson, N., Wilson, G.W.T., Bowker, M.A., Wilson, J.A., and Miller, R.M. 2010. Resource limitation is a driver of local adaptation in mycorrhizal symbiosis. Proc. Natl. Acad. Sci. U.S.A. 107: 2093-2098. doi:10.1073/pnas. 0906710107.

Colpaert, J.V., and van Laere, A. 1996. A comparison of the extracellular enzyme activities of two ectomycorrhizal and a leaf-saprotrophic basidiomycete colonizing beech leaf litter. New Phytol. 133: 133-141. doi:10.1111/j.14698137.1996.tb01153.x.

Colpaert, J.V., van Laere, A., and van Assche, J.A. 1996. Carbon and nitrogen allocation in ectomycorrhizal and non-mycorrhizal Pinus sylvestris L. seedlings. Tree Physiol. 16: 787-793. doi:10.1093/treephys/16.9.787.

Colpaert, J.V., van Laere, A., van Tichelen, K.K., and van Assche, J.A. 1997. The use of inositol hexaphosphate as a phosphorus source by mycorrhizal and nonmycorrhizal Scots pine (Pinus sylvestris). Funct. Ecol. 11: 407-415. doi:10.1046/ j.1365-2435.1997.00103.x.

Comstedt, D., Boström, B., Marshall, J.D., Holm, A., Slaney, M., Linder, S., and Ekblad, A. 2006. Effects of elevated atmospheric carbon dioxide and temperature on soil respiration in a boreal forest using $\delta^{13} \mathrm{C}$ as a labelling tool. Ecosystems, 9: 1266-1277. doi:10.1007/s10021-006-0110-5.

Connell, J.H., and Lowman, M.D. 1989. Low-diversity tropical rainforests: some possible mechanisms for their existence. Am. Nat. 134: 88-119. doi:10.1086/ 284967.

Correa, A., Strasser, R., and Martins-Loucao, M. 2006. Are mycorrhiza always beneficial? Plant Soil, 279: 65-73. doi:10.1007/s11104-005-7460-1.

Correa, A., Strasser, R.J., and Martins-Loucao, M.A. 2008. Response of plants to ectomycorrhizae in N-limited conditions: which factors determine its variation? Mycorrhiza, 18(8): 413-427. doi:10.1007/s00572-008-0195-0.

Correa, A., Hampp, R., Magel, E., and Martins-Loucao, M. 2011. Carbon allocation in ectomycorrhizal plants at limited and optimal $\mathrm{N}$ supply: an attempt at unraveling conflicting theories. Mycorrhiza, 21(1): 35-51. doi:10.1007/s00572010-0309-3.

Correa, A., Gurevitch, J., Martins-Loução, M.A., and Cruz, C. 2012. C allocation to the fungus is not a cost to the plant in ectomycorrhizae. Oikos, 121(3): 449463. doi:10.1111/j.1600-0706.2011.19406.x.

Courty, P.E., Breda, N., and Garbaye, J. 2007. Relation between oak tree phenology and the secretion of organic matter degrading enzymes by Lactarius quietus ectomycorrhizas before and during bud break. Soil Biol. Biochem. 39(7): 1655-1663. doi:10.1016/j.soilbio.2007.01.017.

Courty, P., Buee, M., Diedhiou, A., Frey-Klett, P., Le Tacon, F., Rineau, F., Turpault, M., Uroz, S., and Garbaye, J. 2010. The role of ectomycorrhizal communities in forest ecosystem processes: new perspectives and emerging concepts. Soil Biol. Biochem. 42(5): 679-698. doi:10.1016/j.soilbio.2009.12.006.

Coutts, M.P., and Nicoll, B.C. 1990. Growth and survival of shoots, roots and mycorrhizal mycelium in clonal Sitka spruce during the first growing season after planting. Can. J. For. Res. 20(7): 861-868. doi:10.1139/x90-115.

Cumming, A. 1996. Phosphate limitation physiology in ectomycorrhizal Pitch pine (Pinus rigida) seedlings. Tree Physiol. 16: 977-983. doi:10.1093/treephys/ 16.11-12.977.

Dahlberg, A., and Stenlid, J. 1994. Size, distribution and biomass of genets in populations of Suillus bovinus (L.: Fr.) Roussel revealed by somatic incompatibility. New Phytol. 128: 225-234. doi:10.1111/j.1469-8137.1994.tb04006.x.

Dahlberg, A., Jonsson, L., and Nylund, J.-E. 1997. Species diversity and distribution of biomass above and below ground among ectomycorrhizal fungi in an old-growth Norway spruce forest in south Sweden. Can. J. Bot. 75(8): 13231335. doi:10.1139/b97-844.

Davies, F., Svenson, S., Cole, J., Phavaphutanon, L., Duray, S., Olalde-Portugal, V., et al. 1996. Non-nutritional stress acclimation of mycorrhizal woody plants exposed to drought. Tree Physiol. 16: 985-993. doi:10.1093/treephys/16.11-12. 985.

Deckmyn, G., Campioli, M., Muys, B., and Kraigher, H. 2011. Simulating C and N cycles in forest soils: including the active role of micro-organisms in the ANAFORE forest model. Ecol. Model. 222: 1972-1985. doi:10.1016/j.ecolmodel. 2011.03.011.

Deressa, T.G., and Schenk, M.K. 2008. Contribution of roots and hyphae to phosphorus uptake of mycorrhizal onion (Allium cepa L.) - a mechanistic modelling approach. J. Plant Nutr. Soil Sci. 171: 810-820. doi:10.1002/jpln. 200700209.

Deslippe, J.R., Hartmann, M., Mohn, W.W., and Simard, S.W. 2011. Long-term experimental manipulation of climate alters the ectomycorrhizal commu- nity of Betula nana in Arctic tundra. Glob. Change Biol. 17: 1625-1636. doi:10. 1111/j.1365-2486.2010.02318.x.

di Pietro, M., Churin, J.L., and Garbaye, J. 2007. Differential ability of ectomycorrhizas to survive drying. Mycorrhiza, 17(6): 547-550. doi:10.1007/s00572-0070113-X.

Dickie, I.A., Koide, R.T., and Steiner, K.C. 2002. Influences of established trees on mycorrhizas, nutrition, and growth of Quercus rubra seedlings. Ecol. Monogr. 72: 505-521. doi:10.1890/0012-9615(2002)072[0505:IOETOM]2.0.CO;2.

Dijkstra, P., Ishizu, A.R., and Doucett, P. 2006. ${ }^{13} \mathrm{C}$ and ${ }^{15} \mathrm{~N}$ natural abundance of the soil microbial biomass. Soil Biol. Biochem. 38: 3257-3266. doi:10.1016/j. soilbio.2006.04.005.

Donnelly, D.P., Boddy, L., and Leake, J.R. 2004. Development, persistence and regeneration of foraging ectomycorrhizal mycelial systems in soil microcosms. Mycorrhiza, 14: 37-45. doi:10.1007/s00572-003-0275-0.

Dorneles, M.R.F., da Silva, C.M., and Gomes, A.A. 2001. A model for hyphae effects in phosphorus absorption by plants. Ecol. Model. 142(1-2): 83-89. doi:10.1016/S0304-3800(01)00280-0.

Dorneles, M.R.F., da Silva, C.M., and Gomes, A.A. 2004. A model for hyphaeinduced interaction between plants. Ecol. Model. 174: 323-330. doi:10.1016/j. ecolmodel.2003.09.029.

Druebert, C., Lang, C., Valtanen, K., and Polle, A. 2009. Beech carbon productivity as driver of ectomycorrhizal abundance and diversity. Plant Cell Environ. 32(8): 992-1003. doi:10.1111/j.1365-3040.2009.01983.x.

Durall, D.M., Todd, A.W., and Trappe, J.M. 1994. Decomposition of ${ }^{14}$ C-labelled substrates by ectomycorrhizal fungi in association with Douglas fir. New Phytol. 127(4): 725-729. doi:10.1111/j.1469-8137.1994.tb02976.x.

Egerton-Warburton, L.M., Graham, R.C., and Hubbert, K.R. 2003. Spatial variability in mycorrhizal hyphae and nutrient and water availability in a soil-weathered bedrock profile. Plant Soil, 249: 331-342. doi:10.1023/A: 1022860432113.

Egli, S. 2011. Mycorrhizal mushroom diversity and productivity — an indicator of forest health? Ann. For. Sci. 68: 81-88. doi:10.1007/s13595-010-0009-3.

Ekblad, A., and Högberg, P. 2001. Natural abundance of ${ }^{13} \mathrm{C}$ in $\mathrm{CO}_{2}$ respired from forest soils reveals speed of link between tree photosynthesis and root respiration. Oecologia, 127: 305-308. doi:10.1007/s004420100667.

Ekblad, A., Wallander, H., Carlsson, R., and Huss-Danell, K. 1995. Fungal biomass in roots and extramatrical mycelium in relation to macronutrients and plant biomass of ectomycorrhizal Pinus sylvestris and Alnus incana. New Phytol. 131: 443-451. doi:10.1111/j.1469-8137.1995.tb03081.x.

Ekblad, A., Boström, B., Holm, A., and Comstedt, D. 2005. Forest soil respiration rate and $\delta^{13} \mathrm{C}$ is regulated by recent above ground weather conditions. Oecologia, 143: 136-142. doi:10.1007/s00442-004-1776-z.

Ekblad, A., Wallander, H., Godbold, D.L., Johnson, D., Baldrian, P., Björk, R.G., Cruz, C., Epron, D., Kieliszewska-Rokicka, B., Kjöller, R., Kraigher, H., Matzner, E., Neumann, J., and Plassard, C. 2013. The production and turnover of extramatrical mycelium of ectomycorrhizal fungi in forest soils: role in carbon cycling. Plant Soil, 366: 1-27. doi:10.1007/s11104-013-1630-3.

Ericsson, T. 1995. Growth and shoot:root ratio of seedlings in relation to nutrient availability. Plant Soil, 168/169: 205-214. doi:10.1007/BF00029330.

Fernandez, C.W., Christopher, W., and Koide, R.T. 2012. The role of chitin in the decomposition of ectomycorrhizal fungal litter. Ecology, 93: 24-28. doi:10. 1890/11-1346.1.

Finlay, R. 2008. Ecological aspects of mycorrhizal symbiosis: with special emphasis on the function diversity of interactions involving the extraradical mycelium. J. Exp. Bot. 59: 1115-1126. doi:10.1093/jxb/ern059.

Finlay, R., Ek, H., Odham, G., and Söderström, B. 1988. Mycelial uptake, translocation and assimilation of nitrogen from ${ }^{15} \mathrm{~N}$-labelled ammonium by Pinus sylvestris plants infected with 4 different ectomycorrhizal fungi. New Phytol. 110(1): 59-66. doi:10.1111/j.1469-8137.1988.tb00237.x.

Finlay, R., Ek, H., Odham, G., and Söderström, B. 1989. Uptake, translocation and assimilation of nitrogen from ${ }^{15} \mathrm{~N}$-labelled ammonium and nitrate sources by intact ectomycorrhizal systems of Fagus sylvatica infected with Paxillus involutus. New Phytol. 113(1): 47-55. doi:10.1111/j.1469-8137.1989.tb02394.x.

Finlay, R.D., Wallander, H., Smits, M., Holmström, S., van Hees, P.A.W., Lian, B., and Rosling, A. 2009. The role of fungi in biogenic weathering in forest soils. Fungal Biol. Rev. 23: 101-106. doi:10.1016/j.fbr.2010.03.002.

Finzi, A., Norby, R., Calfapietra, C., Gallet-Budyneka, A., Gielen, B., Holmes, W., Hoosbeek, M., Iverseng, C., Jackson, R., Kubiske, M., Ledford, J., Liberloo, M., Oren, R., Polle, A., Pritchard, S., Zak, D., Schlesinger, W., and Ceulemans, R. 2007. Increases in nitrogen uptake rather than nitrogen-use efficiency support higher rates of temperature forest productivity under elevated $\mathrm{CO}_{2}$. Proc. Natl. Acad. Sci. U.S.A. 104: 14014-14019. doi:10.1073/pnas.0706518104.

Fitter, A.H. 2006. What is the link between carbon and phosphorus fluxes in arbuscular mycorrhizas? A null hypothesis for symbiotic function. New Phytol. 172: 3-6. doi:10.1111/j.1469-8137.2006.01861.x.

Fogel, R., and Hunt, G. 1983. Contribution of mycorrhizae and soil fungi to nutrient cycling in a Douglas-fir ecosystem. Can. J. For. Res. 13(2): 219-232. doi:10.1139/x83-031.

Frey, S.D., Knorr, M., Parrent, J.L., and Simpson, R.T. 2004. Chronic nitrogen enrichment affects the structure and function of the soil microbial community in temperate hardwood and pine forests. For. Ecol. Manage. 196(1): 159171. doi:10.1016/j.foreco.2004.03.018. 
Frey-Klett, P., Garbaye, J., and Tarkka, M. 2007. The mycorrhiza helper bacteria revisited. New Phytol. 176: 22-36. doi:10.1111/j.1469-8137.2007.02191.x.

Gadgil, R.L., and Gadgil, P.D. 1971. Mycorrhiza and litter decomposition. Nature, 233: 133. doi:10.1038/233133a0.

Garbaye, J. 1994. Tansley Review No. 76. Helper bacteria: a new dimension to the mycorrhizal symbiosis. New Phytol. 128: 197-210. doi:10.1111/j.1469-8137.1994. tb04003.x.

Gavito, M., Curtis, P., Mikkelsen, T., and Jakobsen, I. 2000. Atmospheric $\mathrm{CO}_{2}$ and mycorrhiza effetcs on biomass allocation and nutrient uptake of nodulated pea (Pisum sativum L.) plants. New Phytol. 51(352): 1931-1938. doi:10.1093/jexbot/ 51.352.1931.

Gavito, M., Olsson, P., Rouhier, H., Medina-Penafiel, A., Jakobsen, I., Bago, A., and Azcon-Aguilar, C. 2005. Temperature constraints on the growth and functioning of root organ cultures with arbuscular mycorrhizal fungus. New Phytol. 168: 179-188. doi:10.1111/j.1469-8137.2005.01481.x.

Godbold, D.L., Hoosbeek, M.R., Lukac, M., Cotrufo, M.F., Janssens, I.A., Ceulemans, R., Polle, A., Velthorst, E.J., Scarascia-Mugnozza, G., De Angelis, P., Miglietta, F., and Peressotti, A. 2006. Mycorrhizal hyphal turnover as a dominant process for carbon input into soil organic matter. Plant Soil, 281(1): 15-24. doi:10.1007/s11104-005-3701-6.

Grebenc, T., and Kraigher, H. 2009. Interactions in mycorrhizosphere determine carbon dynamics in beech forest ecosystems. Zbornik Gozdarstva in Lesarstva, 88: 11-19.

Gress, S.E., Nichols, T.D., Northcraft, C.C., and Peterjohn, W.T. 2007. Nutrient limitation in soils exhibiting differing nitrogen availabilities: what lies beyond nitrogen saturation? Ecology, 88(1): 119-130. doi:10.1890/00129658(2007)88[119:NLISED]2.0.CO;2.

Hagerberg, D., Thelin, G., and Wallander, H. 2003. The production of ectomycorrhizal mycelium in forests: relation between forest nutrient status and local mineral sources. Plant Soil, 252: 279-290. doi:10.1023/A:1024719607740.

Hammer, E., Pallon, J., Wallander, H., and Olsson, P. 2011. Tit for tat? A mycorrhizal fungus accumulates phosphorus under low plant carbon availability. FEMS Microbiol. Ecol. 76(2): 236-244. doi:10.1111/j.1574-6941.2011.01043.x.

Harley, J.L., and Smith, S.E. 1983. Mycorrhizal symbioses. Academic Press, New York.

Haselwandter, K., Bobleter, O., and Read, D.J. 1990. Utilization of lignin by ericoid and ectomycorrhizal fungi. Arch. Microbiol. 153: 352-354. doi:10.1007| BF00249004.

Hawkes, C., Hartley, I., Ineson, P., and Fitter, A. 2008. Soil temperature affects allocation within arbuscular mycorrhizal networks and carbon transport from plant to fungus. Glob. Change Biol. 14: 1181-1190. doi:10.1111/j.1365-2486. 2007.01535.x.

Hayman, D.S. 1983. The physiology of vesicular-arbuscular endomycorrhizal symbiosis. Can. J. Bot. 61(3): 944-963. doi:10.1139/b83-105.

Hedh, J., Samson, P., Erland, S., and Tunlid, A. 2008. Multiple gene genealogies and species recognition in the ectomycorrhizal fungus Paxillus involutus. Mycol. Res. 112(8): 965-975. doi:10.1016/j.mycres.2008.01.026.

Heinemeyer, A., and Fitter, A. 2004. Impact of temperature on the arbuscular mycorrhizal (AM) symbiosis: growth responses of the host plant and its AM fungal partner. J. Exp. Bot. 55(396): 525-534. doi:10.1093/jxb/erh049.

Heinemeyer, A., Ineson, P., Ostle, N., and Fitter, A. 2006. Respiration of the external mycelium in the arbuscular mycorrhizal symbiosis shows strong dependence on recent photosynthates and acclimation to temperature. New Phytol. 171: 159-170. doi:10.1111/j.1469-8137.2006.01730.x.

Heinemeyer, A., Hartley, I.P., Evans, S.P., Carreira de la Fuentes, J.A., and Ineson, P. 2007. Forest soil $\mathrm{CO}_{2}$ flux: uncovering the contribution and environmental responses of ectomycorrhizas. Glob. Change Biol. 13: 1786-1797. doi:10.1111/j.1365-2486.2007.01383.x.

Heinemeyer, A., Wilkinson, M., Vargas, R., Subke, J.-A., Casella, E., Morison, J.I.L., and Ineson, P. 2011. Exploring the "overflow tap" theory: linking forest soil $\mathrm{CO}_{2}$ fluxes and individual mycorrhizosphere components to photosynthesis. Biogeosci. Disc. 8: 3155-3201. doi:10.5194/bgd-8-3155-2011.

Hobbie, E., and Hobbie, J. 2006. ${ }^{15} \mathrm{~N}$ in symbiotic fungi and plants estimates nitrogen and carbon flux rates in Arctic tundra. Ecology, 87(4): 816-822. doi:10.1890/0012-9658(2006)87[816:NISFAP]2.0.CO;2.

Hobbie, E., and Hobbie, J. 2008. Natural abundance of ${ }^{15} \mathrm{~N}$ in nitrogen-limited forests and tundra can estimate nitrogen cycling through mycorrhiza fungi: a review. Ecosystems, 11: 815-830. doi:10.1007/s10021-008-9159-7.

Högberg, M.N., and Högberg, P. 2002. Extramatrical ectomycorrhizal mycelium contributes one third of microbial biomass and produces, together with associated roots, half the dissolved organic carbon in a forest soil. New Phytol. 154: 791-795. doi:10.1046/j.1469-8137.2002.00417.x.

Högberg, P., and Read, D.J. 2006. Towards a more plant physiological perspective on soil ecology. Trends Ecol. Evol. 21: 548-554. doi:10.1016/j.tree.2006.06.004.

Högberg, P., Högberg, M., Quist, M., Ekblad, A., and Näsholm, T. 1999. Nitrogen isotope fractionation during nitrogen uptake by ectomycorrhizal and nonmycorrhizal Pinus sylvestris. New Phytol. 142: 569-576. doi:10.1046/j.1469-8137. 1999.00404.x.

Högberg, P., Nordgren, A., Buchmann, N., Taylor, A.F.S., Ekblad, A., Högberg, M.N., Nyberg, G., Ottosson-Löfvenius, M., and Read, D.J. 2001. Largescale forest girdling shows that current photosynthesis drives soil respiration. Nature, 411: 789-792. doi:10.1038/35081058.

Hughes, J.K., Hodge, A., Fitter, A.H., and Atkin, O.K. 2008. Mycorrhizal respira- tion: implications for global scaling relationships. Trends Plant Sci. 13: 583588. doi:10.1016/j.tplants.2008.08.010.

Hunt, G.A., and Fogel, R. 1983. Fungal hyphal dynamics in a western Oregon Douglas-fir stand. Soil Biol. Biochem. 15: 641-649. doi:10.1016/0038-0717(83) 90027-5.

Ingham, E.R., Griffiths, R.P., Cromack, K., and Entry, J.A. 1991. Comparison of direct vs fumigation incubation microbial biomass estimates from ectomycorrhizal mat and non-mat soils. Soil Biol. Biochem. 23: 465-471. doi:10.1016/ 0038-0717(91)90011-8.

Jany, J.L., Martin, F., and Garbaye, J. 2003. Respiration activity of ectomycorrhizas from Cenococcum geophilum and Lactarius sp. in relation to soil water potential in five beech forests. Plant Soil, 255(2): 487-494. doi:10.1023/A: 1026092714340.

Johansson, E.M., Fransson, P.M.A., Finlay, R.D., and van Hees, P.A.W. 2009. Quantitative analysis of soluble exudates produced by ectomycorrhizal roots as a response to ambient and elevated $\mathrm{CO}_{2}$. Soil Biol. Biochem. 41: 1111-1116. doi:10.1016/j.soilbio.2009.02.016

Johnson, N.C., Graham, J.H., and Smith, F.A. 1997. Functioning of mycorrhizal associations along the mutualism-parasitism continuum. New Phytol. 135(4): 575-586. doi:10.1046/j.1469-8137.1997.00729.x.

Johnson, T.R., Stewart, S.L., Dytra, D., Kane, M.E., and Richardson, L. 2007. Asymbiotic and symbiotic seed germination of Eulophia alta (Orchidaceae) preliminary evidence for the symbiotic culture advantage. Plant Cell Tissue Organ Cult. 90: 313-323. doi:10.1007/s11240-007-9270-z.

Jolicoeur, M., Bouchard-Marchand, E., Bécard, G., and Perrier, M. 2002. Regulation of mycorrhizal symbiosis: development of a structured nutritional dual model. Ecol. Model. 158: 121-142. doi:10.1016/S0304-3800(02)00168-0.

Jones, D.L., Nguyen, C., and Finlay, R.D. 2009. Carbon flow in the rhizosphere: carbon trading at the soil-root interface. Plant Soil, 321: 5-33. doi:10.1007| s11104-009-9925-0.

Jones, M.D., and Smith, S.E. 2004. Exploring functional definitions of mycorrhizas: are mycorrhizas always mutualisms? Can. J. Bot. 82(8): 1089-1109. doi:10. 1139/b04-110.

Jones, M.D., Durall, D.M., and Tinker, P.B. 1990. Phosphorus relationships and production of extramatrical hyphae by two types of willow ectomycorrhizas at different soil phosphorus levels. New Phytol. 115(2): 259-267. doi:10.1111/j. 1469-8137.1990.tb00451.x.

Kammerbauer, H., Agerer, R., and Sandermann, H. 1989. Studies on ectomycorrhiza. Trees Struct. Funct. 3: 78-84. doi:10.1007/BF01021070.

Katanić, M., Paoletti, E., Orlović, S., Grebenc, T., and Kraigher, H. 2013. Mycorrhizal status of an ozone-sensitive poplar clone treated with the antiozonant ethylene diurea. Eur. J. For. Res. (2013): 1-9. doi:10.1007/s10342-013-0751-9.

Kjøller, R. 2006. Disproportionate abundance between ectomycorrhizal root tips and their associated mycelia. FEMS Microbiol. Ecol. 58: 214-224. doi:10.1111/ j.1574-6941.2006.00166.x.

Kohzu, A., Tateishi, T., Yamada, A., Koba, K., and Wada, E. 2000. Nitrogen isotope fractionation during nitrogen transport from ectomycorrhizal fungi, Suillus granulatus, to the host plant, Pinus densiflora. Soil Sci. Plant Nutr. 46(3): 733739. doi:10.1080/00380768.2000.10409138.

Koide, R.T. 1991. Nutrient supply, nutrient demand and plant response to mycorrhizal infection. New Phytol. 117: 365-386. doi:10.1111/j.1469-8137.1991. tb00001.x.

Koide, R.T., Sharda, J.N., Herr, J.R., and Malcolm, G.M. 2008. Ectomycorrhizal fungi and the biotrophy-saprotrophy continuum. New Phytol. 178: 230-233. doi:10.1111/j.1469-8137.2008.02401.x.

Kowalski, S., Wojewoda, W., Bartnik, C., and Rupik, A. 1990. Mycorrhizal species composition and infection patterns in forest plantations exposed to different levels of industrial pollution. Agric. Ecosyst. Environ. 28(1-4): 249-255. doi: 10.1016/0167-8809(90)90048-I.

Kraigher, H. 1999. Diversity of types of ectomycorrhizae on Norway spruce in Slovenia. Phyton, 39(3): 199-202.

Kuzyakov, Y., Subbotina, I., Chen, H., Bogomolova, I., and Xu, X. 2009. Black carbon decomposition and incorporation into soil microbial biomass estimated by ${ }^{14} \mathrm{C}$ labeling. Soil Biol. Biochem. 41: 210-219. doi:10.1016/j.soilbio. 2008.10.016.

Landeweert, R., Hoffland, E., Finlay, R.D., Kuyper, T.W., and van Breemen, N. 2001. Linking plants to rocks: ectomycorrhizal fungi mobilize nutrients from minerals. Trends Ecol. Evol. 16: 248-254. doi:10.1016/S0169-5347(01)02122-X.

Landeweert, R., Leeflang, P., Kuyper, T.W., Hoffland, E., Rosling, A., Wernars, K., and Smit, E. 2003. Molecular identification of ectomycorrhizal mycelium in soil horizons. Appl. Environ. Microbiol. 69: 327-333. doi:10.1128/AEM.69.1. 327-333.2003.

Landis, F.C., and Fraser, L.H. 2007. A new model of carbon and phosphorus transfers in arbuscular mycorrhizas. New Phytol. 177(2): 466-479. doi:10.1111/ j.1469-8137.2007.02268.x.

Lang, C., and Polle, A. 2011. Ectomycorrhizal fungal diversity, tree diversity and root nutrient relations in a mixed Central European forest. Tree Physiol. 31(5): 531-538. doi:10.1093/treephys/tpr042.

Langley, J.A., and Bruce, A. 2003. Mycorrhizal controls on belowground litter quality. Ecology, 84(9): 2302-2312. doi:10.1890/02-0282.

Langley, J.A., and Hungate, B.A. 2003. Mycorrhizal controls on belowground litter quality. Ecology, 84(9): 2302-2312. doi:10.1890/02-0282.

Langley, J.A., Chapman, S.K., and Hungate, B.A. 2006. Ectomycorrhizal coloniza- 
tion slows root decomposition: the post-mortem fungal legacy. Ecol. Lett. 9(8): 955-959. doi:10.1111/j.1461-0248.2006.00948.x.

Leake, J. 2007. Mycorrhizas and the terrestrial carbon cycle: roles in global carbon sequestration and plant community composition. In Fungi in the environment. Edited by G. Gadd, S. Watkinson, and P. Dyer. Cambridge University Press, Cambridge., pp. 161-185.

Leake, J., Johnson, D., Donnelly, D., Muckle, G., Boddy, L., and Read, D. 2004. Networks of power and influence: the role of mycorrhizal mycelium in controlling plant communities and agroecosystem functioning. Can. J. Bot. 82: 1016-1045. doi:10.1139/b04-060.

Lilleskov, E.A., Fahey, T.J., Horton, T.R., and Lovett, G.M. 2002. Nitrogen deposition and ectomycorrhizal fungal communities: a belowground view from Alaska. Ecology, 83: 104-115. doi:10.1890/0012-9658(2002)083[0104:BEFCCO]2. $0 . \mathrm{CO} ; 2$.

Lindahl, B.D., Ihrmark, K., Boberg, J., Trumbore, S.E., Högberg, P., Stenlid, J., and Finlay, R.D. 2007. Spatial separation of litter decomposition and mycorrhizal nitrogen uptake in a boreal forest. New Phytol. 173: 611-620. doi:10.1111/j.14698137.2006.01936.x.

Linder, S. 1995. Foliar analysis for detecting and correcting nutrient imbalances in Norway spruce. Ecol. Bull. 44: 178-190.

Luo, Z.B., Janz, D., Jiang, X., Göbel, C., Wildhagen, H.G., Tan, Y., Rennenberg, H., Feussner, I., and Polle, A. 2009. Upgrading root physiology for stress tolerance by ectomycorrhizas: insights from metabolite and transcriptional profiling into reprogramming for stress anticipation. Plant Physiol. 151: 1902-1917. doi:10.1104/pp.109.143735.

Lynch, J.M., and Harper, S.H.T. 1974. Formation of ethylene by a soil fungus. J. Gen. Microbiol. 85: 91-96. doi:10.1099/00221287-85-1-91.

Majdi, H., Damm, E., and Nylund, J.E. 2001. Longevity of mycorrhizal roots depends on branching order and nutrient availability. New Phytol. 150: 1-8. doi:10.1046/j.1469-8137.2001.00089.x.

Malcolm, G., Lopez-Gutierrez, J., Koide, R., and Eissenstat, D. 2008. Acclimation to temperature and temperature sensivity of metabolism by ectomycorrhizal fungi. Glob. Change Biol. 14: 1169-1180. doi:10.1111/j.1365-2486.2008.01555.x.

Marschner, H., and Dell, B. 1994. Nutrient uptake in mycorrhizal symbiosis. Plant Soil, 159: 89-102. doi:10.1007/BF00000098.

Marshall, J.D., and Perry, D.A. 1987. Basal and maintenance respiration of mycorrhizal and nonmycorrhizal root systems of conifers. Can. J. For. Res. 17(8): 872-877. doi:10.1139/x87-138.

Martin, C.A., and Stutz, J.C. 2004. Interactive effects of temperature and arbuscular mycorrhizal fungi on growth, $\mathrm{P}$ uptake and root respiration of Capsicum annuum L. Mycorrhiza, 14: 241-244. doi:10.1007/s00572-003-0261-6.

Martin, F., Aerts, A., Ahrén, D., Brun, A., Danchin, E.G.J., Duchaussoy, F., Gibon, J., Kohler, A., Lindquist, E., Pereda, V., Salamov, A., Shapiro, H.J., Wuyts, J., Blaudez, D., and Buée, M. 2008. The genome of Laccaria bicolor provides insights into mycorrhizal symbiosis. Nature, 452: 88-92. doi:10.1038/ nature 06556 .

Matyssek, R., Wieser, G., Ceulemans, R., Rennenberg, H., Pretzsch, H., Haberer, K., Löw, M., Nunn, A.J., Werner, H., Wipfler, P., Osswald, W., Nikolova, P., Hanke, D.E., Kraigher, H., Tausz, M., Bahnweg, G., Kitao, M., Dieler, J., Sandermann, H., Herbinger, K., Grebenc, T., Blumenröther, M., Deckmyn, G., Grams, T.E., Heerdt, C., Leuchner, M., Fabian, P., and Häberle, K.H. 2010. Enhanced ozone strongly reduces carbon sink strength of adult beech (Fagus sylvatica) - resume from the free-air fumigation study at Kranzberg Forest. Environ. Pollut. 158(8): 2527-2532. doi:10.1016/j.envpol. 2010.05.009.

Meyer, A., Grote, R., Polle, A., and Butterbach-Bahl, K. 2010. Simulating mycorrhiza contribution to forest $\mathrm{C}$ - and N-cycling - the MYCOFON model. Plant Soil, 327: 493-517. doi:10.1007/s11104-009-0017-y.

Meyer, A., Grote, R., and Butterbach-Bahl, K. 2012. Integrating mycorrhiza in a complex model system - effects on ecosystem C and N fluxes. Eur. J. For. Res. 131(6): 1809-1831. doi:10.1007/s10342-012-0634-5.

Miller, R.M., Reinhardt, D.R., and Jastrow, J.D. 1995. External hyphal production of vesicular-arbuscular mycorrhizal fungi in pasture and tallgrass prairie communities. Oecologia, 103: 17-23.

Morin, C., Samson, J., and Dessureault, M. 1999. Protection of black spruce seedlings against Cylindrocladium root rot with ectomycorrhizal fungi. Can. J. Bot. 77(1): 169-174. doi:10.1139/b99-025.

Moyano, F., Kutsch, W., and Schulze, E. 2007. Response of mycorrhizal, rhizosphere and soil basal respiration to temperature and photosynthesis in a barley field. Soil Biol. Biochem. 39: 843-863. doi:10.1016/j.soilbio.2006.10.001.

Nagendran, S., Hallen-Adams, H.E., Paper, J.M., Aslam, N., and Walton, J.D. 2009. Reduced genomic potential for secreted plant cell-wall-degrading enzymes in the ectomycorrhizal fungus Amanita bisporigera, based on the secretome of Trichoderma reesei. Fungal Genet. Biol. 46: 427-435. doi:10.1016/j.fgb.2009.02. 001.

Naples, B.K., and Fisk, M.C. 2010. Belowground insights into nutrient limitation in northern hardwood forests. Biogeochemistry, 97: 109-121. doi:10.1007| s10533-009-9354-4.

Nehls, U. 2008. Mastering ectomycorrhizal symbiosis: the impact of carbohydrates. J. Exp. Bot. 59(5): 1097-1108. doi:10.1093/jxb/erm334.

Nehls, U., Gohringer, F., Wittulsky, S., and Dietz, S. 2010. Fungal carbohydrate support in the ectomycorrhizal symbiosis: a review. Plant Biol. 12(2): 292-301. doi:10.1111/j.1438-8677.2009.00312.x.
Neuhauser, C., and Fargione, J. 2004. A mutualism-parasitism continuum model and its application to plant-mycorrhizae interactions. Ecol. Model. 177: 337352. doi:10.1016/j.ecolmodel.2004.02.010.

Nilsson, L.O., and Wallander, H. 2003. Production of external mycelium by ectomycorrhizal fungi in a Norway spruce forest was reduced in response to nitrogen fertilization. New Phytol. 158: 409-416. doi:10.1046/j.1469-8137.2003. 00728.x.

Nilsson, L., Baath, E., Falkengren-Grerup, U., and Wallander, H. 2007. Growth of ectomycorrhizal mycelia and composition of soil microbial communities in oak forest soils along a nitrogen deposition gradient. Oecologia, 153(2): 375384. doi:10.1007/s00442-007-0735-x.

Norkrans, B. 1950. Studies in growth and cellulolytic enzymes of Tricholoma. Symb. Bot. Ups. 11: 1-126.

Orwin, K.H., Kirschbaum, M.U.M., St. John, G., and Dickie, I.A. 2011. Organic nutrient uptake by mycorrhizal fungi enhances ecosystem carbon storage: a model-based assessment. Ecol. Lett. 14(5):493-502. doi:10.1111/j.1461-0248.2011. 01611.x.

Ostonen, I., and Löhmus, K. 2003. Proportion of fungal mantle, cortex and stele of ectomycorrhizas in Picea abies (L.) Karst. in different soils and site conditions. Plant Soil, 257: 435-442. doi:10.1023/A:1027305906159.

Ostonen, I., Lõhmus, K., and Pajuste, K. 2005. Fine root biomass, production and its proportion of NPP in a fertile middle-aged Norway spruce stand: comparison of soil core and ingrowth core methods. For. Ecol. Manage. 212: 264-277. doi:10.1016/j.foreco.2005.03.064.

Parrent, J.L., and Vilgalys, R. 2007. Biomass and compositional responses of ectomycorrhizal fungal hyphae to elevated $\mathrm{CO}_{2}$ and nitrogen fertilization. New Phytol. 176: 164-174. doi:10.1111/j.1469-8137.2007.02155.x.

Parrent, J.L., Morris, W.F., and Vilgalys, R. 2006. $\mathrm{CO}_{2}$-enrichment and nutrient availability alter ectomycorrhizal fungal communities. Ecology, 87(9): 22782287. doi:10.1890/0012-9658(2006)87[2278:CANAAE]2.0.CO;2.

Pena, R., Offermann, C., Simon, J., Naumann, P., Gessler, A., Holst, J., Dannenmann, M., Mayer, H., Kogel-Knabner, I., Rennenberg, H., and Polle, A. 2010. Girdling affects ectomycorrhizal fungal (EMF) diversity and reveals functional differences in EMF community composition in a beech forest. Appl. Environ. Microbiol. 76(6): 1831-1841. doi:10.1128/AEM.01703-09.

Phillips, C.L., Kluber, L.A., Martin, J.P., Caldwell, B.A., and Bond, B.J. 2012. Contributions of ectomycorrhizal fungal mats to forest soil respiration. Biogeosciences, 9: 2099-2110. doi:10.5194/bg-9-2099-2012.

Pietikäinen, A., Kytöviita, M.-M., and Vuoti, U. 2005. Mycorrhiza and seedling establishment in a subarctic meadow: effects of fertilization and defoliation. J. Veg. Sci. 16: 175-182. doi:10.1111/j.1654-1103.2005.tb02353.x.

Plassard, C., and Dell, B. 2010. Phosphorus nutrition of mycorrhizal trees. Tree Physiol. 30: 1129-1139. doi:10.1093/treephys/tpq063.

Plassard, C., Schroemm, P., Mouisan, D., and Salsac, L. 1991. Assimilation of mineral nitrogen and ion balance in the two partners of ectomycorrhizal symbiosis: data and hypothesis. Cell. Mol. Life Sci. 47: 340-349. doi:10.1007| BF01972075.

Plett, J., and Martin, F. 2011. Blurred boundaries: lifestyle lessons from ectomycorrhizal fungal genomes. Trends Genet. 27(1): 14-22. doi:10.1016/j.tig.2010. 10.005.

Poorter, H., and Nagel, O. 2000. The role of biomass allocation in the growth response of plants to different levels of light, $\mathrm{CO}_{2}$, nutrients and water: a quantitative view. Aust. J. Plant Physiol. 27: 595-607. doi:10.1071/PP99173_CO.

Prieto, I., Padilla, F.M., Armas, C., and Pugnaire, F.I. 2011. The role of hydraulic lift on seedling establishment under a nurse plant species in a semi-arid environment. Perspect. Plant Ecol. Evol. Syst. 13: 181-187. doi:10.1016/j.ppees. 2011.05.002.

Pritchard, S.G., Strand, A.E., McCormack, M.L., Davis, M.A., and Oren, R. 2008. Mycorrhizal and rhizomorph dynamics in a loblolly pine forest during 5 years of free-air- $\mathrm{CO}_{2}$-enrichment. Glob. Change Biol. 14: 1252-1264. doi:10. 1111/j.1365-2486.2008.01567.x.

Raidl, S. 1997. Studien zur Ontogenie an Rhizomorphen von Ektomykorrhizen. Biblioth. Mycol. 169: 1-1840.

Read, D.J. 1992. The mycorrhizal mycelium. In Mycorrhizal functioning. Edited by M.F. Allen. Chapman and Hall, London, UK. pp. 102-133.

Read, D.J., Leake, J.R., and Perez-Moreno, J. 2004. Mycorrhizal fungi as drivers of ecosystem processes in heathland and boreal forest biomes. Can. J. Bot. 82(8): 1243-1263. doi:10.1139/b04-123.

Read, D., and Perez-Moreno, J. 2003. Mycorrhizas and nutrient cycling in ecosystems - a journey towards relevance? New Phytol. 157: 475-492. doi:10.1046/j.1469-8137.2003.00704.x.

Rillig, M.C., and Mummey, D.L. 2006. Mycorrhizas and soil structure. New Phytol. 171: 41-53. doi:10.1111/j.1469-8137.2006.01750.x.

Rillig, M.C., Bruce, A., Caldwell, M., Han, A.B., and Wösten, P.S. 2007. Role of proteins in soil carbon and nitrogen storage: controls on persistence. Biogeochemistry, 85: 25-44. doi:10.1007/s10533-007-9102-6.

Rinaldi, A.C., Comandini, O., and Kuyper, T.W. 2008. Ectomycorrhizal fungal diversity: separating the wheat from the chaff. Fungal Divers. 33: 1-45.

Rineau, F., Roth, D., Shah, F., and Smits, M. 2012. The ectomycorrhizal fungus Paxillus involutus converts organic matter in plant litter using a trimmed brown-rot mechanism involving Fenton chemistry. Environ. Microbiol. 14(6): 1477-1487. doi:10.1111/j.1462-2920.2012.02736.x.

Rineau, F., Shah, F., Smits, M.M., Persson, P., Johansson, T., Carleer, R., Troein, C., 
and Tunlid, A. 2013. Carbon availability triggers the decomposition of plant litter and assimilation of nitrogen by an ectomycorrhizal fungus. ISME J. 7: 2010-2022. doi:10.1038/ismej.2013.91.

Rosling, A., Landeweert, R., Lindahl, B.D., Larsson, K.-H., Kuyper, T.W., Taylor, A.F.S., and Finlay, R.D. 2003. Vertical distribution of ectomycorrhizal fungal taxa in a podzol soil profile. New Phytol. 159: 775-783. doi:10.1046/j. 1469-8137.2003.00829.x.

Runion, G.B., Mitchell, R.J., Rogers, H.H., Prior, S.A., and Counts, T.K. 1997. Effects of nitrogen and water limitation and elevated atmospheric $\mathrm{CO}_{2}$ on ectomycorrhiza of longleaf pine. New Phytol. 137(4): 681-689. doi:10.1046/j. 1469-8137.1997.00865.x.

Ruotsalainen, A.L., Väre, H., and Vestberg, M. 2002. Seasonality of root fungal colonization in low-alpine herbs. Mycorrhiza, 12(1): 29-36. doi:10.1007/s00572001-0145-6.

Rygewiecz, P.T., and Andersen, C.P. 1994. Mycorrhizae alter quality and quantity of carbon allocated below ground. Nature, 369: 58-60. doi:10.1038/369058a0.

Rygiewicz, P.T., Johnson, M.G., Ganio, L., Tingey, D.T., and Storm, M. 1997a. Lifetime and temporal occurrence of Pinus ponderosa seedling ectomycorrhizae grown under varying atmospheric $\mathrm{CO}_{2}$ and nitrogen levels. Plant Soil, 189: 275-287. doi:10.1023/A:1004210709108.

Rygiewicz, P.T., Martin, K.J., and Tuininga, A.R. 1997b. Global climate change and diversity of mycorrhizae. In Progress in microbial ecology. Edited by M.T. Martins, M.I.Z. Sato, J.M. Tiedje, L.C.N. Hagler, J.D. Bereiner, and P.S. Sanchez. Brazilian Society for Microbiology. pp. 91-98.

Sangtiean, T., and Smith, S. 2002. Growth of subtropical ECM fungi with different nitrogen sources using a new floating culture technique. Mycol. Res. 106(1): 74-85. doi:10.1017/S0953756201005226.

Schnepf, A., and Roose, T. 2006. Modelling the contribution of arbuscular mycorrhizal fungi to plant phosphate uptake. New Phytol. 171(3): 669-682. doi: 10.1111/j.1469-8137.2006.01771.x.

Schnepf, A., Roose, T., and Schweiger, P. 2008. Impact of growth and uptake patterns of arbuscular mycorrhizal fungi on plant phosphorus uptake - a modelling study. Plant Soil, 312(1-2): 85-99. doi:10.1007/s11104-008-9749-3.

Shi, L.B., Guttenberger, M., Kottke, I., and Hampp, R. 2002. The effect of drought on mycorrhizas of beech (Fagus sylvatica L.): changes in community structure, and the content of carbohydrates and nitrogen storage bodies of the fungi. Mycorrhiza, 12(6): 303-311. doi:10.1007/s00572-002-0197-2.

Simard, S.W., Jones, M.D., Durall, D.M., Perry, D.A., Myrold, D.D., and Molina, R. 1997. Reciprocal transfer of carbon isotopes between ectomycorrhizal Betula papyrifera and Pseudotsuga menziesii. New Phytol. 137(3): 529-542. doi:10.1046/ j.1469-8137.1997.00834.x.

Simard, S.W., Jones, M.D., and Durall, D.M. 2002. Carbon and nutrient fluxes within and between mycorrhizal plants. In Mycorrhizal ecology. Edited by M.G.A. van der Heijden and I. Sanders. Springer-Verlag, Berlin. pp. 33-74.

Smith, S.E., and Read, D.J. 2008. Mycorrhizal symbiosis. 3rd ed. Academic Press, London.

Söderström, B. 1979. Seasonal fluctuations of active fungal biomass in horizons of a podzolized pine-forest soil in central Sweden. Soil Biol. Biochem. 11: 149-154. doi:10.1016/0038-0717(79)90093-2.

Son, C.L., and Smith, S.E. 1988. Mycorrhizal growth responses: interactions between photon irradiance and phosphorus nutrition. New Phytol. 108: 305314. doi:10.1111/j.1469-8137.1988.tb04167.x.

Staddon, P.L. 1998. Insights into mycorrhizal colonisation at elevated $\mathrm{CO}_{2}$ : a simple carbon partitioning model. Plant Soil, 205: 171-180. doi:10.1023/A: 1004388605110

Staddon, P.L., Heinemeyer, A., and Fitter, A.H. 2002. Mycorrhizas and global environmental change: research at different scales. Plant Soil, 244: 253-261. doi:10.1023/A:1020285309675.

Staddon, P., Ramsey, C., Ostle, N., Ineson, P., and Fitter, A. 2003. Rapid turnover of hyphae of mycorrhizal fungi determined by AMS microanalysis of C-14. Science, 300(5622): 1138-1140. doi:10.1126/science.1084269.

Stahl, P.D., Parkin, T.B., and Eash, N.S. 1995. Sources of error in direct microscopic methods for estimation of fungal biomass in soil. Soil Biol. Biochem. 27: 1091-1097. doi:10.1016/0038-0717(94)00204-E.

Swaty, R.L., Deckert, R.J., Whitham, T.G., and Gehring, C.A. 2004. Ectomycorrhizal abundance and community composition shifts with drought: predictions from tree rings. Ecology, 85(4): 1072-1084. doi:10.1890/03-0224.

Talbot, J.M., Allison, S.D., and Treseder, K.K. 2008. Decomposers in disguise: mycorrhizal fungi as regulators of soil $\mathrm{C}$ dynamics in ecosystems under global change. Funct. Ecol. 22: 955-963. doi:10.1111/j.1365-2435.2008.01402.x.

Taylor, A., and Alexander, I. 2005. The ectomycorrhizal symbiosis: life in the real world. Mycologist, 19: 102-112. doi:10.1017/S0269915X05003034.

Taylor, A.F.S., Hogbom, L., Högberg, M., Lyon, A.J.E., Nasholm, T., and Högberg, P. 1997. Natural ${ }^{15} \mathrm{~N}$ abundance in fruit bodies of ectomycorrhizal fungi from boreal forests. New Phytol. 136(4): 713-720. doi:10.1046/j.14698137.1997.00788.x.

Taylor, A.F.S., Fransson, P.M., Högberg, P., Högberg, M.N., and Plamboeck, A.H. 2003. Species level patterns in ${ }^{13} \mathrm{C}$ and ${ }^{15} \mathrm{~N}$ abundance of ectomycorrhizal and saprotrophic fungal sporocarps. New Phytol. 159: 757-774. doi:10.1046/j.14698137.2003.00838.x.

Thelin, G., Rosengren, U., and Nihlgård, B. 2002. Barrkemi på Skånska Gran- och Tallprovytor, Rapport 20. County Administrative Board of Skåne, Malmö, Sweden.
Thornley, J.H.M., and Cannell, M.G.R. 2000. Modelling the components of respiration: representation and realism. Ann. Bot. 85: 55-67. doi:10.1006/anbo. 1999.0997.

Treseder, K. 2004. A meta-analysis of mycorrhizal responses to nitrogen, phosphorus, and atmospheric $\mathrm{CO}_{2}$ in field studies. New Phytol. 164: 347-355. doi:10.1111/j.1469-8137.2004.01159.x.

Treseder, K., Allen, M.F., Ruess, R.W., Pregitzer, K.S., and Hendrick, R.L. 2005. Lifespans of fungal rhizomorphs under nitrogen fertilization in a pinyonjuniper woodland. Plant Soil, 270(1): 249-255. doi:10.1007/s11104-004-1559-7.

Trocha, L.K., Mucha, J., Eissenstat, M., Reich, P.B., and Oleksyn, J. 2010. Ectomycorrhizal identity determines respiration and concentrations of nitrogen and non-structural carbohydrates in root tips: a test using Pinus sylvestris and Quercus robur saplings. Tree Physiol. 30: 648-654. doi:10.1093/treephys/ tpq014.

Trojanowski, J., Haider, K., and Hüttermann, A. 1984. Decomposition of ${ }^{14} \mathrm{C}-$ labelled lignin, holocellulose and lignocellulose by mycorrhizal fungi. Arch. Microbiol. 139: 202-206. doi:10.1007/BF00402000.

Trumbore, S.E. 1997. Potential responses of soil organic carbon to global environmental change. Proc. Natl. Acad. Sci. U.S.A. 94: 8284-8291. doi:10.1073/ pnas.94.16.8284.

Trumbore, S. 2006. Carbon respired by terrestrial ecosystems - recent progress and challenges. Glob. Change Biol. 12: 141-153. doi:10.1111/j.1365-2486.2006. 01067.x.

Unestam, T., and Sun, Y.-P. 1995. Extramatrical structures of hydrophobic and hydrophilic ectomycorrhizal fungi. Mycorrhiza, 5: 301-311. doi:10.1007| BF00207402.

Van Tichelen, K.K., and Colpaert, J.V. 2000. Kinetics of phosphate absorption by mycorrhizal and non-mycorrhizal Scots pine seedlings. Physiol. Plant. 110: 96-103. doi:10.1034/j.1399-3054.2000.110113.x.

van der Heijden, M.G.A., Bardgett, R.D., and van Straalen, N.M. 2008. The unseen majority: soil microbes as drivers of plant diversity and productivity in terrestrial ecosystems. Ecol. Lett. 11(3): 296-310. doi:10.1111/j.1461-0248.2007. 01139.x.

Vargas, R., and Allen, M.F. 2008. Dynamics of fine root, fungal rhizomorphs, and soil respiration in a mixed temperate forest: integrating sensors and observations. Vadose Zone J. 7: 1055-1064. doi:10.2136/vzj2007.0138.

Verbruggen, E., El Mouden, C., Jansa, J., Akkermans, G., Bücking, H., West, S.A., and Kiers, E.T. 2012. Spatial structure and interspecific cooperation: theory and an empirical test using the mycorrhiza mutualism. Am. Nat. 179: E133E146. doi:10.1086/665032.

Veresoglou, S.D., and Halley, J.M. 2012. A model that explains diversity patterns of arbuscular mycorrhizas. Ecol. Model. 231:146-152. doi:10.1016/j.ecolmodel. 2012.01.026.

Vitousek, P.M., and Howarth, R.W. 1991. Nitrogen limitations on land and in the sea: how can it occur? Biogeochemistry, 13: 87-115. doi:10.1007/BF00002772.

Vogt, K.A., Grier, C.C., Meier, C.E., and Edmonds, R.L. 1982. Mycorrhizal role in net primary production and nutrient cycling in Abies amabilis ecosystems in western Washington. Ecology, 63: 370-380. doi:10.2307/1938955.

Volkmer, C. 1999. Untersuchungen zur Stress-Sensitivität von Ökotypen der Buche (Fagus sylvatica L.). Dissertation, University of Freiburg, Germany.

Wallander, H. 1995. A new hypothesis to explain allocation of dry matter between mycorrhizal fungi and pine seedlings in relation to nutrient supply. Plant Soil, 168-169: 243-248. doi:10.1007/BF00029334.

Wallander, H., and Nylund, J.-E. 1992. Effects of excess nitrogen and phosphorus starvation on the extramatrical mycelium of ectomycorrhizas of Pinus sylverstris L. New Phytol. 120: 495-503. doi:10.1111/j.1469-8137.1992.tb01798.x.

Wallander, H., Nilsson, L.O., Hagerberg, D., and Bååth, E. 2001. Estimation of the biomass and production of external mycelium of ectomycorrhizal fungi in the field. New Phytol. 151: 753-760. doi:10.1046/j.0028-646x.2001.00199.x.

Wallander, H., Mahmood, S., Hagerberg, D., Johansson, L., and Pallon, J. 2003. Elemental composition of ectomycorrhizal mycelia identified by PCR-RFLP analysis and grown in contact with apatite or wood ash in forest soil. FEMS Microbiol. Ecol. 44(1): 57-65.

Wallander, H., Göransson, H., and Rosengreen, U. 2004. Production, standing biomass and natural abundance of ${ }^{15} \mathrm{~N}$ and ${ }^{13} \mathrm{C}$ in ectomycorrhizal mycelia collected at different soil depth in two forest types. Oecologia, 139: 89-97. doi:10.1007/s00442-003-1477-z.

Wallander, H., Johansson, U., Sterkenburg, E., Brandström, M., and Lindahl, B. 2010. Production of ectomycorrhizal mycelium peaks during canopy closure in Norway spruce forests. New Phytol. 187: 1124-1134. doi:10.1111/j.1469-8137. 2010.03324.x

Wallander, H., Ekblad, A., and Bergh, J. 2011. Growth and carbon sequestration by ectomycorrhizal fungi in intensively fertilized Norway spruce forests. For. Ecol. Manage. 262(6): 999-1007. doi:10.1016/j.foreco.2011.05.035.

Wallander, H., Ekblad, A., Godbold, D.L., Johnson, D., Bahr, A., Baldrian, P., Björk, R.G., Kieliszewska-Rokicka, B., Kjøller, R., Kraigher, H., Plassard, C., and Rudawska, M. 2013. Evaluation of different methods to estimate production, biomass and turnover of mycorrhizal mycelium - a review. Soil Biol. Biochem. 57: 1034-1047. doi:10.1016/j.soilbio.2012.08.027.

Wallenda, T., and Kottke, I. 1998. Nitrogen deposition and ectomycorrhizas. New Phytol. 139: 169-187. doi:10.1046/j.1469-8137.1998.00176.x.

Warren, J.M., Brooks, J.R., Meinzer, F.C., and Eberhart, J.L. 2008. Hydraulic redistribution of water from Pinus ponderosa trees to seedlings: evidence for an 
ectomycorrhizal pathway. New Phytol. 178(2): 382-394. doi:10.1111/j.1469-8137. 2008.02377.x.

Weigt, R.B., Raidl, S., Verma, R., and Agerer, R. 2012. Exploration type-specific standard values of extramatrical mycelium - a step towards quantifying ectomycorrhizal space occupation and biomass in natural soil. Mycol. Prog. 11: 287-297. doi:10.1007/s11557-011-0750-5.

Wiemken, V., Ineichen, K., and Boller, T. 2001. Development of ectomycorrhizas in model beech-spruce ecosystems on siliceous and calcareous soil: a 4-year experiment with atmospheric $\mathrm{CO}_{2}$ enrichment and nitrogen fertilization. Plant Soil, 234(1): 99-108. doi:10.1023/A:1010500400263.
Wiklund, K., Nilsson, L.-O., and Jacobsson, S. 1994. Effects of irrigation, fertilisation, and artificial drought on basidioma production in a Norway spruce stand. Can. J. Bot. 73(2): 200-208. doi:10.1139/b95-023.

Yi, Z., Fu, S., Yi, W., Zhou, G., Mo, J., Zhang, D., Ding, M., Wang, X., and Zhou, L. 2007. Partitioning soil respiration in lower subtropical forests at different successional stages in southern China. For. Ecol. Manage. 243: 178-186. doi: 10.1016/j.foreco.2007.02.022.

Zeller, B., Brechet, C., Maurice, J.-P., and Le Tacon, F. 2007. ${ }^{13} \mathrm{C}$ and ${ }^{15} \mathrm{~N}$ isotopic fractionation in trees, soils and fungi in a natural forest stand and a Norway spruce plantation. Ann. For. Sci. 64(4): 419-429. doi:10.1051/forest:2007019. 